\title{
\#USGS
}

science for a changing world

Prepared in cooperation with the

New York State Department of Environmental Conservation

\section{Groundwater Quality in the Lake Champlain and Susquehanna River Basins, New York, 2014}

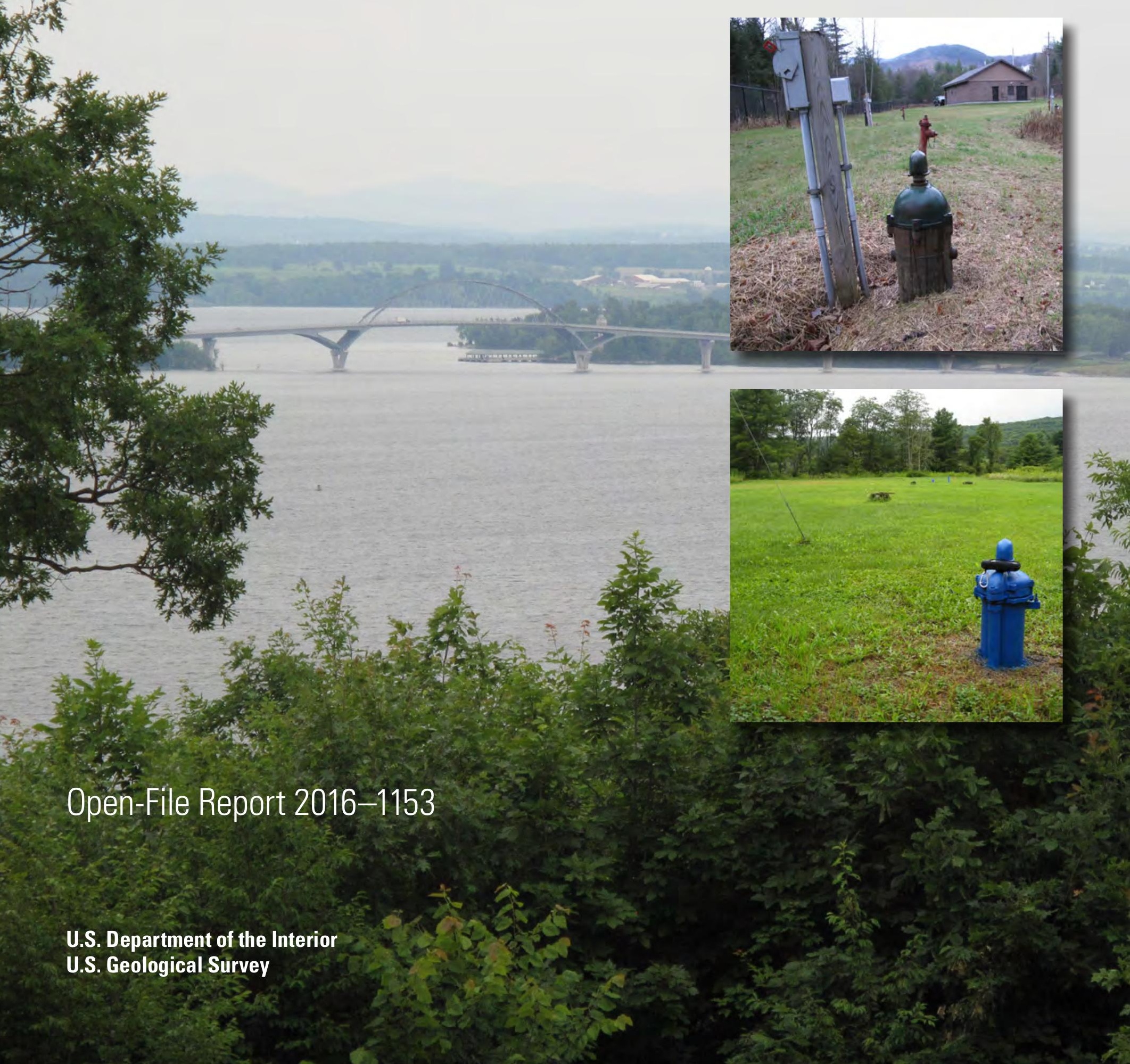


Cover.

Background. View of the Champlain Bridge over Lake Champlain from a domestic well in Essex County, New York. Top. Setting of a production well in Essex County.

Bottom. Setting of a production well in Otsego County, N.Y.; photograph by James E. Reddy, U.S. Geological Survey. 


\section{Groundwater Quality in the Lake Champlain and Susquehanna River Basins, New York, 2014}

By Tia-Marie Scott, Elizabeth A. Nystrom, and James E. Reddy

Prepared in cooperation with the

New York State Department of Environmental Conservation

Open-File Report 2016-1153 


\section{U.S. Department of the Interior SALLY JEWELL, Secretary}

\section{U.S. Geological Survey Suzette M. Kimball, Director}

\section{U.S. Geological Survey, Reston, Virginia: 2016}

For more information on the USGS - the Federal source for science about the Earth, its natural and living resources, natural hazards, and the environment-visit http://www.usgs.gov or call 1-888-ASK-USGS.

For an overview of USGS information products, including maps, imagery, and publications, visit http://store.usgs.gov.

Any use of trade, firm, or product names is for descriptive purposes only and does not imply endorsement by the U.S. Government.

Although this information product, for the most part, is in the public domain, it also may contain copyrighted materials as noted in the text. Permission to reproduce copyrighted items must be secured from the copyright owner.

Suggested citation:

Scott, T.-M., Nystrom, E.A., and Reddy, J.E., 2016, Groundwater quality in the Lake Champlain and Susquehanna River basins, New York, 2014: U.S. Geological Survey Open-File Report 2016-1153, 33 p., appendixes, http://dx.doi.org/10.3133/ofr20161153.

ISSN 2331-1258 (online) 


\section{Acknowledgments}

The authors extend thanks and appreciation to all well owners who took the time to fill out well surveys and to those who gave permission and facilitated sampling of their wells. Thanks are also extended to our contacts at the New York State Department of Environmental Conservation, New York State Department of Health, county departments of health, and all the public water supply personnel who provided information and help with this study. Additionally, the authors would like to extend thanks and appreciation to U.S. Geological Survey personnel James Kruegler and Benjamin Fisher for their work collecting the samples. 



\section{Contents}

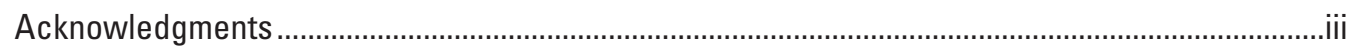

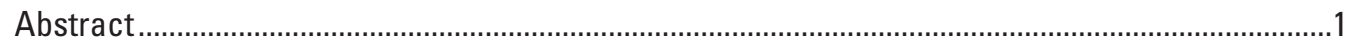

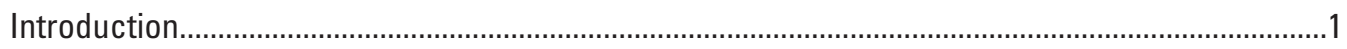

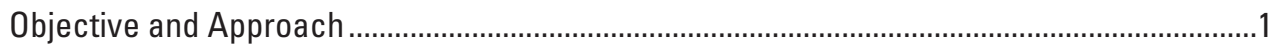

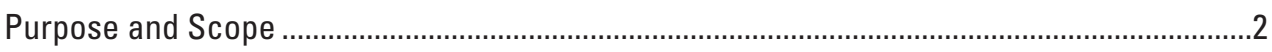

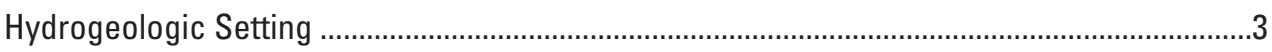

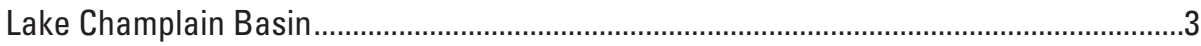

Susquehanna River Basin ..........................................................................................

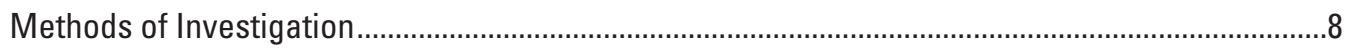

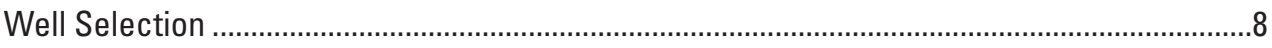

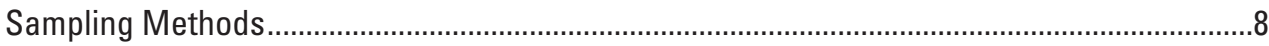

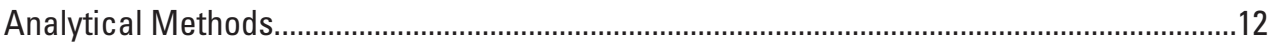

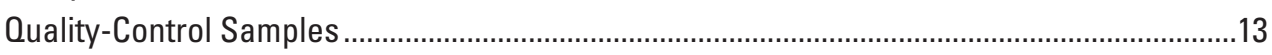

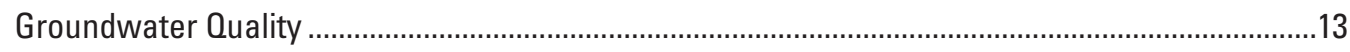

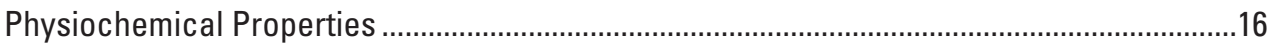

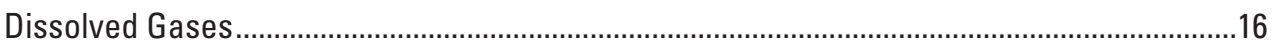

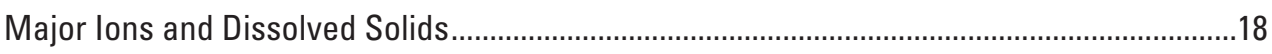

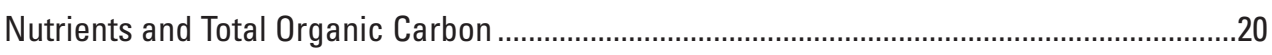

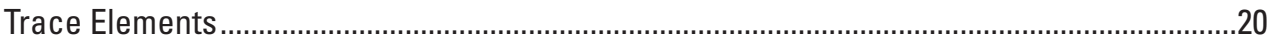

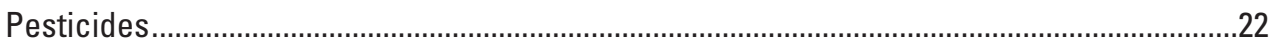

Volatile Organic Compounds..............................................................................................24

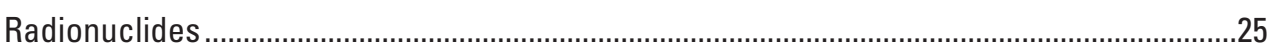

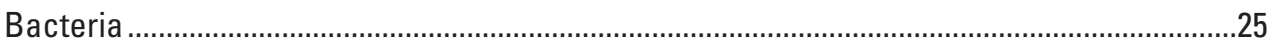

Comparison of Results From Wells Sampled in 2004-05, 2009, and 2014 .............................27

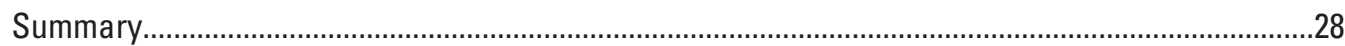

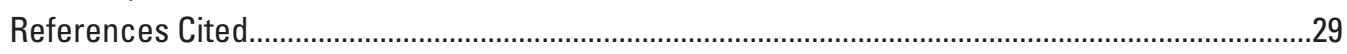

Appendix 1. Results of Water-Sample Analyses, 2014 ..............................................................3

Appendix 2. Results of Water-Sample Analyses, 2004-05, 2009, and 2014.................................33

\section{Figures}

1. Map showing topography and geography of the Lake Champlain Basin,

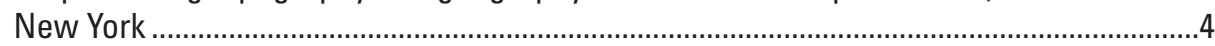

2. Map showing generalized bedrock geology of the Lake Champlain Basin, New York, and locations of wells sampled in 2014 .........................................................5

3. Map showing generalized surficial geology of the Lake Champlain Basin, New York, and locations of wells sampled in 2014 ........................................................

4. Map showing topography and geography of the Susquehanna River Basin, New York......

5. Map showing generalized bedrock geology of the Susquehanna River Basin, New York, and locations of wells sampled in 2014 ....................................................9

6. Map showing generalized surficial geology of the Susquehanna River Basin, New York, and locations of wells sampled in 2014 


\section{Tables}

1. Previous groundwater-quality studies and reports of the rotating-basin groundwater monitoring program in New York.

2. Description of wells from which water samples were collected in the Lake Champlain and Susquehanna River Basins, New York, 2014.

3. Summary of 33 wells from which water samples were collected in the Lake Champlain and Susquehanna River Basins, New York, 2014.

4. Constituents that exceeded primary and (or) secondary drinking-water standards in groundwater samples collected in the Lake Champlain and Susquehanna River Basins, New York, 2014

5. Summary statistics for physiochemical properties of groundwater samples collected in the Lake Champlain and Susquehanna River Basins, New York, 2014

6. Drinking-water standards for physiochemical properties and dissolved gases and number of groundwater samples exceeding those standards collected in the Lake Champlain and Susquehanna River Basins, New York, 2014.

7. Summary statistics for concentrations of major ions in groundwater samples collected in the Lake Champlain and Susquehanna River Basins, New York, 2014 ........19

8. Drinking-water standards for concentrations of major ions and number of groundwater samples exceeding those standards collected in the Lake Champlain and Susquehanna River Basins, New York, 2014.

9. Summary statistics for concentrations of nutrients in groundwater samples collected in the Lake Champlain and Susquehanna River Basins, New York, 2014........21

10. Drinking-water standards for concentrations of nutrients and number of groundwater samples exceeding those standards collected in the Lake Champlain and Susquehanna River Basins, New York, 2014.

11. Summary statistics for concentrations of trace elements in groundwater collected in the Lake Champlain and Susquehanna River Basins, New York, 2014........23

12. Drinking-water standards for concentrations of trace elements and number of groundwater samples exceeding those standards collected in the Lake Champlain and Susquehanna River Basins, New York, 2014.

13. Summary statistics for activities of radionuclides in groundwater samples collected in the Lake Champlain and Susquehanna River Basins, New York, 2014........26

14. Drinking-water standards for activities of radionuclides and number of groundwater samples exceeding those standards collected in the Lake Champlain and Susquehanna River Basins, New York, 2014. 


\section{Conversion Factors}

U.S. customary units to International System of Units

\begin{tabular}{lcl}
\hline \multicolumn{1}{c}{ Multiply } & By & \multicolumn{1}{c}{ To obtain } \\
\hline inch (in.) & 2.54 & centimeter $(\mathrm{cm})$ \\
foot (ft) & 0.3048 & meter $(\mathrm{m})$ \\
mile (mi) & 1.609 & kilometer $(\mathrm{km})$ \\
square mile $\left(\mathrm{mi}^{2}\right)$ & 259.0 & hectare $(\mathrm{ha})$ \\
square mile $\left(\mathrm{mi}^{2}\right)$ & 2.590 & square kilometer $\left(\mathrm{km}^{2}\right)$ \\
gallon (gal) & 3.785 & liter $(\mathrm{L})$ \\
picocurie per liter $(\mathrm{pCi} / \mathrm{L})$ & 0.037 & becquerel per liter $(\mathrm{Bq} / \mathrm{L})$ \\
\hline
\end{tabular}

Temperature in degrees Celsius $\left({ }^{\circ} \mathrm{C}\right)$ may be converted to degrees Fahrenheit $\left({ }^{\circ} \mathrm{F}\right)$ as follows:

$$
{ }^{\circ} \mathrm{F}=\left(1.8 \times{ }^{\circ} \mathrm{C}\right)+32 \text {. }
$$

\section{Datum}

Vertical coordinate information is referenced to the North American Vertical Datum of 1988 (NAVD 88).

Horizontal coordinate information is referenced to the North American Datum of 1983 (NAD 83).

Elevation, as used in this report, refers to distance above the vertical datum.

\section{Supplemental Information}

Specific conductance is given in microsiemens per centimeter at 25 degrees Celsius $(\mu \mathrm{S} / \mathrm{cm}$ at $\left.25^{\circ} \mathrm{C}\right)$.

Concentrations of chemical constituents in water are given in milligrams per liter (mg/L). 


\section{Abbreviations}

$\begin{array}{ll}\text { AMCL } & \text { alternative maximum contaminant level } \\ \text { CFU } & \text { colony-forming units } \\ \mathrm{CH}_{4} & \text { methane } \\ \text { CIAT } & \text { 2-chloro-4-isopropylamino-6-amino-s-triazine } \\ \mathrm{CO}_{2} & \text { carbon dioxide } \\ \text { EPA } & \text { U.S. Environmental Protection Agency } \\ \text { GC-MS } & \text { gas chromatography-mass spectrometry } \\ \text { ICP-AES } & \text { inductively coupled plasma-atomic emission spectrometry } \\ \text { LRL } & \text { laboratory reporting level } \\ \text { MCL } & \text { maximum contaminant level } \\ \text { MTBE } & \text { methyl tert-butyl ether } \\ \text { NWIS } & \text { National Water Information System } \\ \text { NWOL } & \text { National Water Quality Laboratory } \\ \text { NYSDEC } & \text { New York State Department of Environmental Conservation } \\ \text { NYSDOH } & \text { New York State Department of Health } \\ \text { SDWS } & \text { secondary drinking-water standards } \\ \text { THM } & \text { trihalomethane } \\ \text { USGS } & \text { U.S. Geological Survey } \\ \text { VOC } & \text { volatile organic compound } \\ & \end{array}$




\title{
Groundwater Quality in the Lake Champlain and Susquehanna River Basins, New York, 2014
}

\author{
By Tia-Marie Scott, Elizabeth A. Nystrom and James E. Reddy
}

\section{Abstract}

In a study conducted by the U.S. Geological Survey in cooperation with the New York State Department of Environmental Conservation, groundwater samples were collected from 6 production wells and 7 domestic wells in the Lake Champlain Basin and from 11 production wells and 9 domestic wells in the Susquehanna River Basin in New York. All samples were collected from June through December 2014 to characterize groundwater quality in these basins. The samples were collected and processed using standard procedures of the U.S. Geological Survey and were analyzed for 148 physiochemical properties and constituents, including dissolved gases, major ions, nutrients, trace elements, pesticides, volatile organic compounds, radionuclides, and indicator bacteria.

The Lake Champlain Basin study area covers the 3,050 square miles of the basin in northeastern New York; the remaining part of the basin is in Vermont and Canada. Of the 13 wells sampled in the Lake Champlain Basin, 6 are completed in sand and gravel, and 7 are completed in bedrock. Groundwater in the Lake Champlain Basin was generally of good quality, although properties and concentrations of some constituents - fluoride, iron, manganese, dissolved solids, sodium, radon-222, total coliform bacteria, fecal coliform bacteria, and Escherichia coli bacteria—sometimes equaled or exceeded primary, secondary, or proposed drinking-water standards. The constituent most frequently detected in concentrations exceeding drinking-water standards (5 of 13 samples) was radon-222.

The Susquehanna River Basin study area covers the entire 4,522 square miles of the basin in south-central New York; the remaining part of the basin is in Pennsylvania. Of the 20 wells sampled in the Susquehanna River Basin, 11 are completed in sand and gravel, and 9 are completed in bedrock. Groundwater in the Susquehanna River Basin was generally of good quality, although properties and concentrations of some constituents $-\mathrm{pH}$, chloride, sodium, dissolved solids, iron, manganese, aluminum, arsenic, barium, gross- $\alpha$ radioactivity, radon-222, methane, total coliform bacteria, and fecal coliform bacteria - sometimes equaled or exceeded primary, secondary, or proposed drinking-water standards. As in the Lake Champlain Basin, the constituent most frequently detected in concentrations exceeding drinking-water standards (13 of 20 samples) was radon-222.

\section{Introduction}

Groundwater is used as a source of drinking water by approximately one-quarter of the more than 19 million population of New York State (Kenny and others, 2009; U.S. Census Bureau, 2016). In 2002, the U.S. Geological Survey (USGS), in cooperation with the New York State Department of Environmental Conservation (NYSDEC), developed a program to evaluate groundwater quality throughout the major river basins in New York on a rotating basis. The program parallels the NYSDEC Rotating Integrated Basin Studies Program (http://www.dec.ny.gov/ chemical/30951.html), which evaluates surface-water quality on a 5 -year cycle by sampling in 2 or 3 of the 14 major river basins in the State each year. This program also supports NYSDEC's responsibilities under section 305(b) of the Federal Water Pollution Control Act Amendments of 1972 (Clean Water Act) to report on the chemical quality of groundwater within New York (U.S. Environmental Protection Agency, 1997). The groundwater-quality program began with a pilot study in the Mohawk River Basin in 2002 and has continued throughout upstate New York (upstate refers to New York State north of New York City) since then (table 1). Sampling completed in 2008 represents the conclusion of the first round of groundwater-quality sampling throughout upstate New York State. Groundwater-quality sampling was conducted in 2014 in the Lake Champlain and Susquehanna River Basins, beginning the third round of groundwaterquality sampling for this program.

\section{Objective and Approach}

The objective of the groundwater-quality monitoring program is to quantify and report on ambient groundwater quality in bedrock and glacial-drift aquifers in upstate New York. Using consistent, standardized methods, groundwaterquality samples were collected from existing domestic and production wells, equipped with permanently installed pumps. Wells were selected to represent an approximately equal number of domestic and production wells, to represent an approximately equal number of bedrock and glacial-drift wells, and to provide a representative geographic distribution of samples with emphasis on areas of greatest groundwater 
Table 1. Previous groundwater-quality studies and reports of the rotating-basin groundwater monitoring program in New York.

[Reports listed in bold indicate the previous groundwater-quality studies in the Lake Champlain Basin and the Susquehanna River Basin]

\begin{tabular}{|c|c|c|c|}
\hline Study area & Year & Report & Reference \\
\hline Mohawk River Basin & 2002 & Water-Data Report NY-02-1 & Butch and others, 2003 \\
\hline Chemung River Basin & 2003 & Open-File Report 2004-1329 & Hetcher-Aguila, 2005 \\
\hline Lake Champlain Basin & 2004 & Open-File Report 2006-1088 & Nystrom, 2006 \\
\hline Susquehanna River Basin & 2004 & Open-File Report 2006-1161 & Hetcher-Aguila and Eckhardt, 2006 \\
\hline Delaware River Basin & 2005 & Open-File Report 2007-1098 & Nystrom, 2007a \\
\hline Genesee River Basin & 2005 & Open-File Report 2007-1093 & Eckhardt and others, 2007 \\
\hline St. Lawrence River Basin & 2005 & Open-File Report 2007-1066 & Nystrom, 2007b \\
\hline Mohawk River Basin & 2006 & Open-File Report 2008-1086 & Nystrom, 2008 \\
\hline Western New York & 2006 & Open-File Report 2008-1140 & Eckhardt and others, 2008 \\
\hline Central New York & 2007 & Open-File Report 2009-1257 & Eckhardt and others, 2009 \\
\hline Upper Hudson River Basin & 2007 & Open-File Report 2009-1240 & Nystrom, 2009 \\
\hline Chemung River Basin & 2008 & Open-File Report 2011-1112 & Risen and Reddy, 2011a \\
\hline Eastern Lake Ontario Basin & 2008 & Open-File Report 2011-1074 & Risen and Reddy, 2011b \\
\hline Lower Hudson River Basin & 2008 & Open-File Report 2010-1197 & Nystrom, 2010 \\
\hline Lake Champlain Basin & 2009 & Open-File Report 2011-1180 & Nystrom, 2011 \\
\hline Susquehanna River Basin & 2009 & Open-File Report 2012-1045 & Reddy and Risen, 2012 \\
\hline Delaware River Basin & 2010 & Open-File Report 2011-1320 & Nystrom, 2012 \\
\hline Genesee River Basin & 2010 & Open-File Report 2012-1135 & Reddy, 2012 \\
\hline St. Lawrence River Basin & 2010 & Open-File Report 2011-1320 & Nystrom, 2012 \\
\hline Mohawk River Basin & 2011 & Open-File Report 2013-1021 & Nystrom and Scott, 2013 \\
\hline Western New York & 2011 & Open-File Report 2013-1095 & Reddy, 2013 \\
\hline Central New York & 2012 & Open-File Report 2014-1226 & Reddy, 2014 \\
\hline Upper Hudson River Basin & 2012 & Open-File Report 2014-1084 & Scott and Nystrom, 2014 \\
\hline Chemung River Basin & 2013 & Open-File Report 2015-1168 & Scott and others, 2015 \\
\hline Eastern Lake Ontario Basin & 2013 & Open-File Report 2015-1168 & Scott and others, 2015 \\
\hline Lower Hudson River Basin & 2013 & Open-File Report 2015-1168 & Scott and others, 2015 \\
\hline
\end{tabular}

use. Approximately 20 percent of samples were collected from wells that previously have been sampled as part of the cycle of studies. Samples were analyzed for a broad suite of constituents, including physiochemical properties and concentrations of dissolved gases, major ions, nutrients, trace elements, pesticides, volatile organic compounds (VOCs), radionuclides, and indicator bacteria. The resulting dataset will be used to establish a groundwater-quality baseline for New York State that characterizes naturally occurring and ambient conditions and to identify long-term trends. The data are made available through the USGS National Water Information System (NWIS; http://nwis.waterdata.usgs.gov/ny/nwis/qw) and published reports.

Groundwater-quality samples were collected in the Lake Champlain Basin in 2004-05, 2009, and 2014, and in the Susquehanna River Basin in 2004-05, 2009, and 2014. In 2014, from June through December, 13 environmental samples and 1 quality-assurance sample were collected in the Lake Champlain Basin. Twenty environmental samples and two quality-assurance samples were collected in the Susquehanna River Basin. Three of the Lake Champlain Basin wells sampled in 2014 were also sampled as part of this cycle of studies in 2009 (Nystrom, 2011); two of those wells were also sampled in the 2004-05 cycle of this study (Nystrom, 2006). Three of the Susquehanna River Basin wells were also sampled as part of this cycle of studies in 2009 (Reddy and Risen, 2012); one of those wells was also sampled in the 2004-05 cycle of this study (Hetcher-Aguila and Eckhardt, 2006).

\section{Purpose and Scope}

This report presents the findings of the 2014 groundwater-quality study in the Lake Champlain Basin 
and the Susquehanna River Basin. Thirteen samples from the Lake Champlain Basin and 20 samples from the Susquehanna River Basin were collected from June through December 2014. The report (1) describes the hydrogeologic setting, the methods of site selection, wells that were sampled, sample collection, and chemical analysis; (2) presents discussions of the analytical results; (3) presents comparisons of analytical results to drinking-water-quality guidelines, and (4) presents comparisons of the results of this study with results for selected wells in the study areas that were sampled in 2004-05 and 2009 (Hetcher-Aguila and Eckhardt, 2006; Nystrom, 2006, 2011; Reddy and Risen, 2012).

\section{Hydrogeologic Setting}

The study areas discussed in this report cover more than 7,500 square miles $\left(\mathrm{mi}^{2}\right)$, or 14 percent of New York State, and represent a wide range of geologic, hydrologic, and topographic settings, and land uses. Bedrock lithology ranges from complex mixtures of crystalline, metamorphic, and carbonate rock in the Lake Champlain Basin to primarily shale and sandstone with some carbonate rock in the Susquehanna Basin. Surficial material in the study areas mainly consists of glacial and alluvial deposits.

\section{Lake Champlain Basin}

The Lake Champlain Basin encompasses 8,250 $\mathrm{mi}^{2}$ in New York, Vermont, and Quebec, Canada. The groundwatermonitoring study area includes only the 3,050- $\mathrm{mi}^{2}$ part of the Lake Champlain Basin that lies within New York (fig. 1). The study area includes parts of five counties - Clinton, Essex, Franklin, Warren, and Washington (fig. 1). Major tributaries to Lake Champlain in New York include the Ausable River, Saranac River, Salmon River, Great Chazy River, Boquet River, La Chute River, and Mettawee River; large lakes in the basin include Lake Champlain and Lake George. The Champlain Canal connects Lake Champlain to the Hudson River at Fort Edward.

The highest elevations in the Lake Champlain Basin study area are more than 5,000 feet (ft) above the North American Vertical Datum of 1988 (NAVD 88) on the western edge of the basin, in the Adirondack Mountains (fig. 1). The lowest elevations in the basin are at Lake Champlain (about $100 \mathrm{ft}$ above NAVD 88). Precipitation throughout the Lake Champlain Basin falls mostly as rain. Precipitation in the Lake Champlain Valley lowland areas averages about 35 inches per year (in/yr), whereas precipitation in the cooler Adirondack Mountains averages about 45 in/yr (Giese and Hobba, 1970). Urban centers and adjacent developed areas in the Lake Champlain Basin study area include Glens Falls, Queensbury, and Plattsburgh (fig. 1). Land use in the basin is primarily forested, especially in the upland areas, with urban and agriculture uses mainly in valleys and other low-lying areas (Vogelmann and others, 2001).
Bedrock in the Lake Champlain Basin study area (fig. 2) is mainly crystalline rock with small areas of carbonate rock, sandstone, and shale. The Adirondack Mountains are underlain mainly by crystalline metamorphic rock, including granitic gneiss, meta-anorthosite, and olivine metagabbro (Isachsen and others, 2000). The Champlain and St. Lawrence Valleys are underlain by sandstone, carbonate rocks (including limestone and dolostone), shale, and metamorphosed clastic rocks (Isachsen and others, 2000). Yields from bedrock wells in the study area vary greatly, but the carbonate units generally produce the greatest yields, and the crystalline units generally produce the smallest (Giese and Hobba, 1970). The surficial material throughout the study area (fig. 3) was deposited primarily during the Pleistocene epoch when the Wisconsinan glaciers covered most of the northeastern United States (Isachsen and others, 2000). Till, which was directly deposited by the glaciers, discontinuously overlies bedrock in the uplands (fig. 3). Lacustrine sand, silt, and clay underlie much of the lowlands bordering Lake Champlain. Ice contact and outwash sand and gravel, which were deposited by glacial meltwater, and recent alluvium, underlie the larger stream and river valleys. Till and lacustrine deposits generally yield low amounts of water, whereas saturated sand and gravel deposits form the most productive aquifers in the study area (Giese and Hobba, 1970).

\section{Susquehanna River Basin}

The Susquehanna River Basin study area encompasses 4,522 $\mathrm{mi}^{2}$ in south-central New York, north of the Pennsylvania border. The study area contains parts of 14 counties, including most of Cortland, Chenango, Otsego, Broome, and Tioga Counties; and parts of Tompkins, Schuyler, Chemung, Onondaga, Madison, Oneida, Herkimer, Schoharie, and Delaware Counties (fig. 4). Major tributaries to the Susquehanna River include the Chenango River, Tioughnioga River, Unadilla River, Otselic River, Nanticoke River, Owego Creek, Catatonk Creek, Cayuta Creek, Genegantslet Creek, Butternut Creek, Wharton Creek, Ouleout Creek, Otego Creek, Cherry Valley Creek, Schenevus Creek, and Charlotte Creek (fig. 4). The Susquehanna River Basin ultimately drains into the Chesapeake Bay watershed (fig. 4).

The highest elevations in the Susquehanna River Basin study area are more than 2,700 ft above NAVD 88 in the western Catskill Mountains (fig. 4). The lowest elevations in the study area are about $750 \mathrm{ft}$ above NAVD 88, near the downstream end of the Susquehanna River valley (fig. 4). Precipitation in the Susquehanna River Basin averages around $40 \mathrm{in} / \mathrm{yr}$ (Randall, 1996). Land use in the study area is predominantly rural, although it contains the small cities of Oneonta, Binghamton, Norwich, and Cortland (fig. 4). Most of the developed areas are within the Susquehanna, Unadilla, Chenango, and Tioughnioga River valleys (fig. 4). The main valley of the Susquehanna River trends northeast to southwest and is about 1 mile wide in most places. 


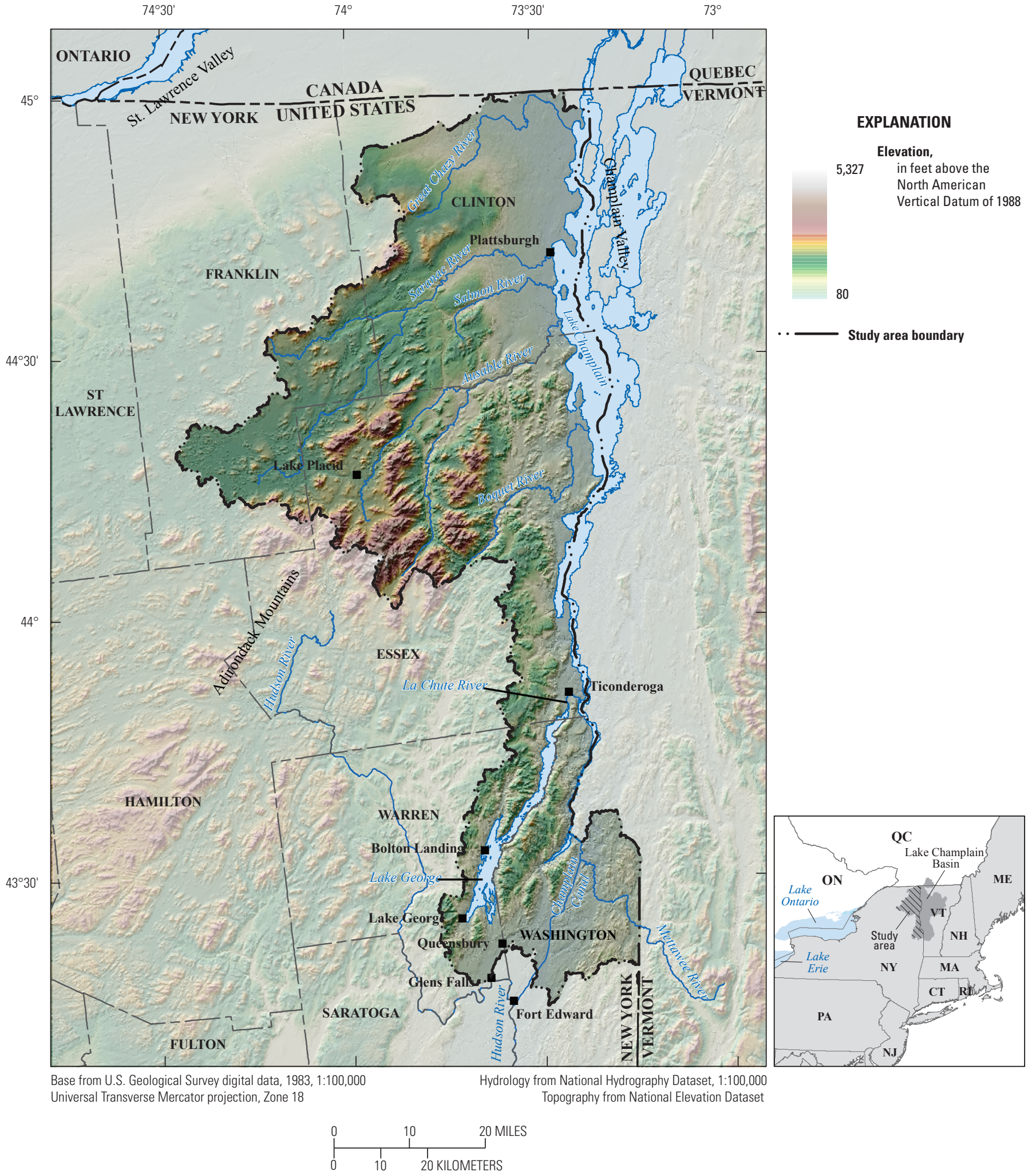

Figure 1. Topography and geography of the Lake Champlain Basin, New York. 


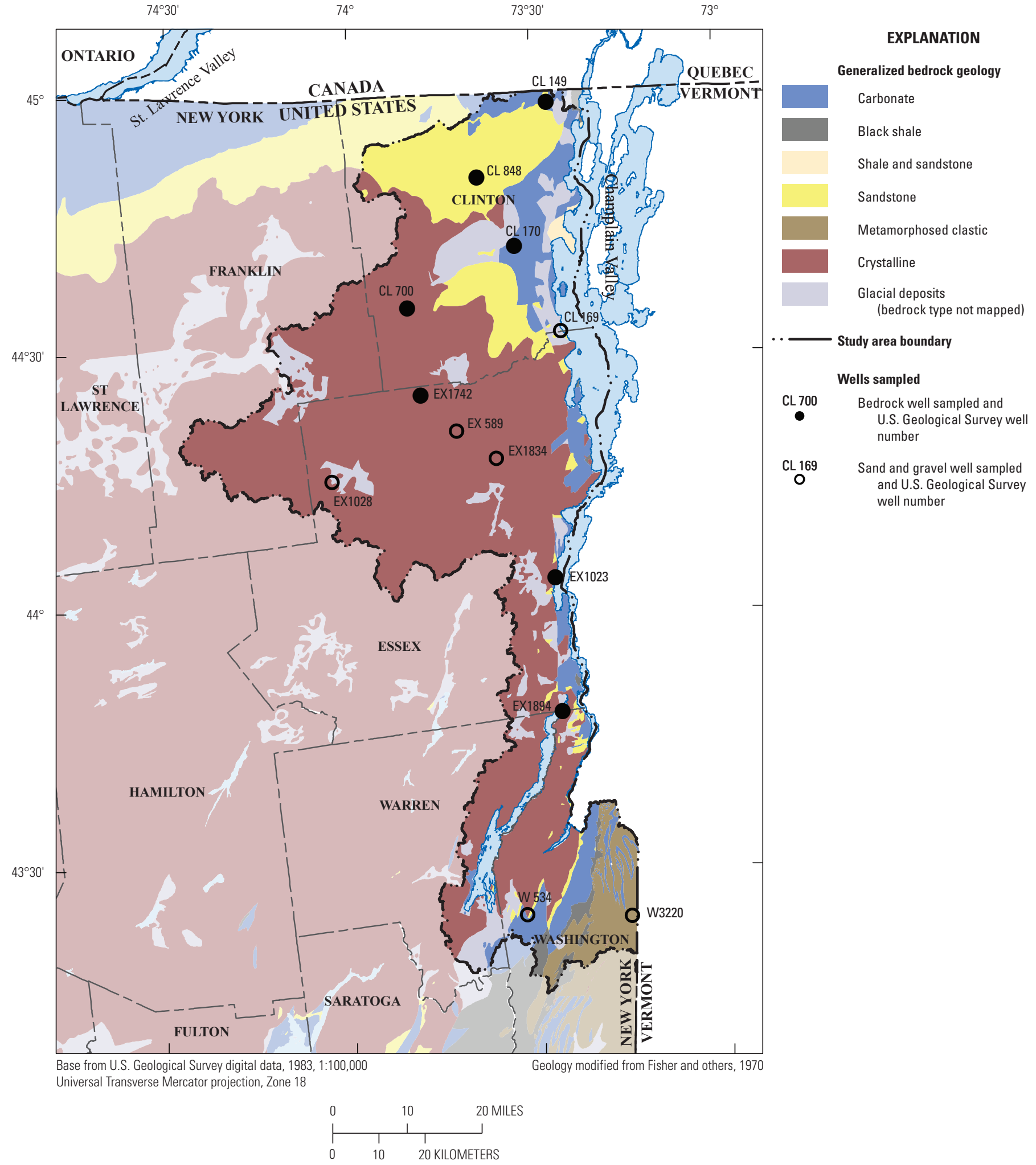

Figure 2. Generalized bedrock geology of the Lake Champlain Basin, New York, and locations of wells sampled in 2014. 


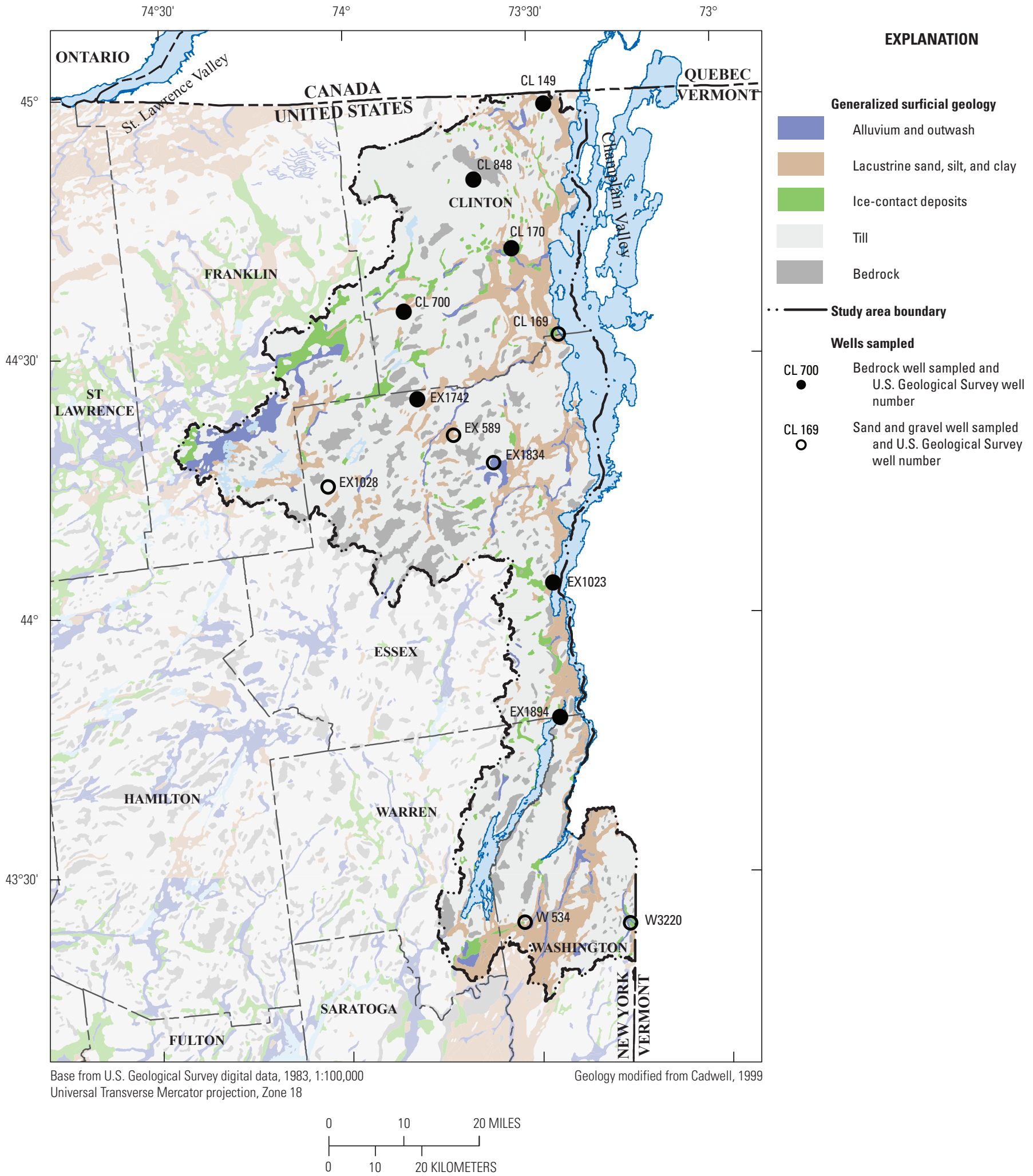

Figure 3. Generalized surficial geology of the Lake Champlain Basin, New York, and locations of wells sampled in 2014. 

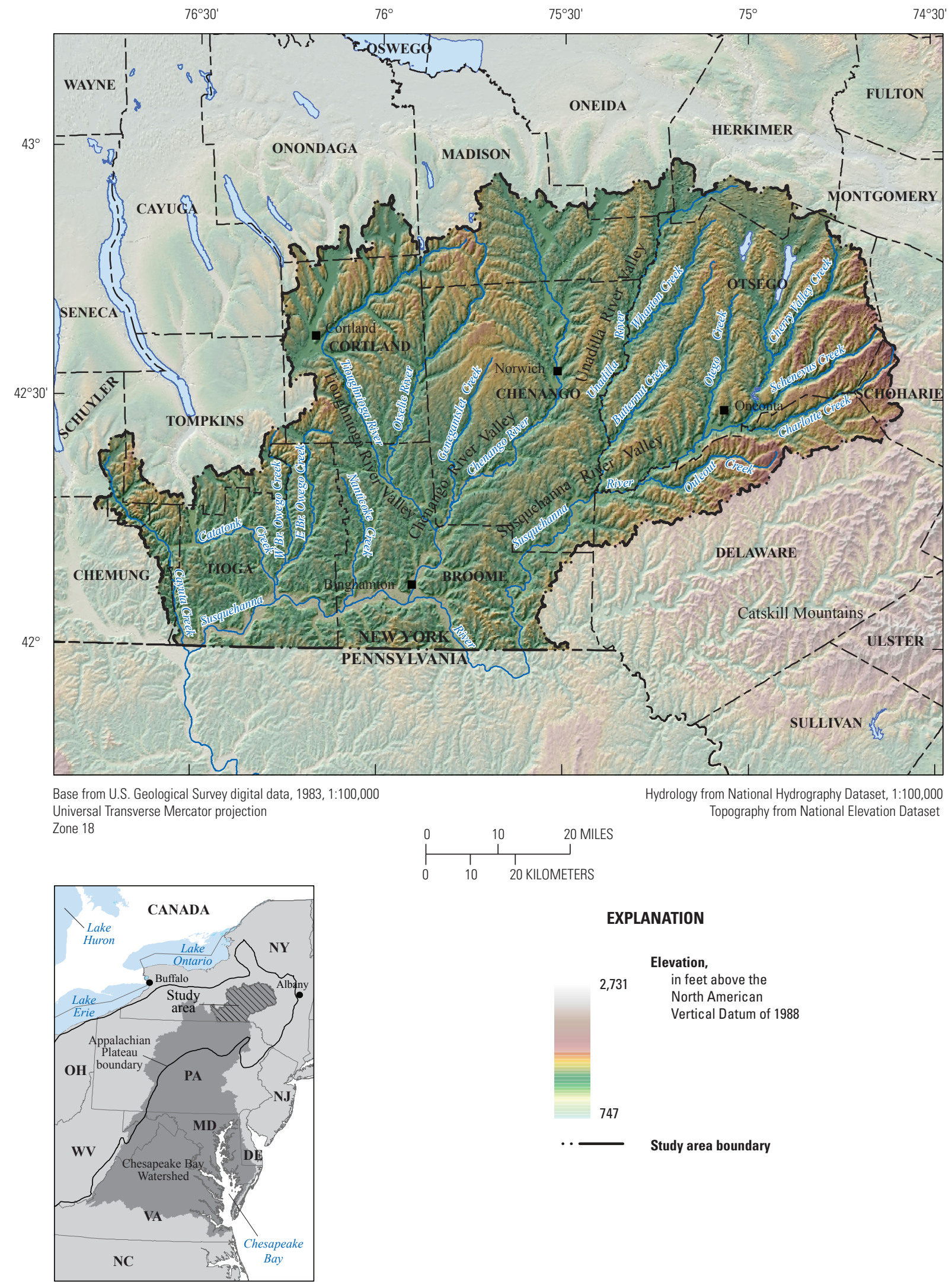

EXPLANATION

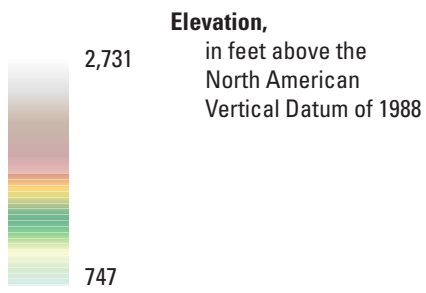

Study area boundary

Figure 4. Topography and geography of the Susquehanna River Basin, New York. 
Bedrock in the Susquehanna River Basin (fig. 5) mainly consists of fractured shale and sandstone; small areas in the northern part of the basin consist of fractured and solutioned limestone and dolostone (Reddy and Risen, 2012). The surficial material throughout the Susquehanna River Basin was deposited primarily during the Pleistocene epoch when the Wisconsinan glaciers covered most of the northeastern United States (Isachsen and others, 2000). Till, which was directly deposited by the glaciers, discontinuously overlies bedrock in the uplands (fig. 6). Ice contact and outwash sand and gravel and lacustrine sand, silt, and clay were deposited mainly in valleys. Recent alluvium overlies the glacial deposits in the flood plains of the larger streams and rivers (Randall, 2001; Coates, 1966).

\section{Methods of Investigation}

Well selection criteria, sampling methods, and analytical methods were designed to maximize data precision, accuracy, and comparability. Groundwater-sample collection and processing followed standard USGS procedures as documented in the National Field Manual for the Collection of Water-Quality Data (U.S. Geological Survey, n.d.). Samples were analyzed at the USGS National Water Quality Laboratory (NWQL) in Denver, Colorado, and other certified laboratories using published methods.

\section{Well Selection}

The 33 wells selected for sampling (figs. 2 and 5) represent forested, developed, and agricultural areas (table 2). The final selection of each well was based on the availability of well construction data and hydrogeologic information for the well and its surrounding area. The study did not target specific municipalities, industries, or agricultural practices. Wells were selected to represent an approximately equal number of domestic and production wells.

The domestic wells were selected on the basis of information from the NYSDEC Water Well Program, which began in 2000. The program requires that licensed well drillers file a report with NYSDEC containing basic information about each well drilled, such as well and casing depth, diameter, yield, and a driller's log. Evaluation of well completion report data identified several hundred wells as potential sampling sites; well owners were sent a letter requesting permission to sample the well and a questionnaire about the well. Well owners who granted permission were contacted later by phone to verify well information and to arrange for sampling.

Production wells considered for sampling were identified through the U.S. Environmental Protection Agency (EPA) Safe Drinking Water Information System, the New York State Department of Health (NYSDOH) Drinking Water Protection Program, and the NYSDEC Water Well Program. Town officials and (or) water managers were sent letters requesting permission to sample a well, and followup phone calls were made to arrange a time for sampling. Well information, such as depth, was provided by water managers if a well completion report was unavailable. The aquifer type indicated for sampled wells was assigned through evaluation of driller's logs and published geologic maps, including Fisher and others (1970) and Cadwell (1999).

The characteristics of the wells sampled, the USGSassigned county well numbers of production and domestic wells, and the type of land cover surrounding each well are listed in table 2. The depths of the wells and the aquifer units from which samples were collected are summarized in tables 2 and 3. Three Lake Champlain Basin wells sampled in 2014 (CL 149, EX 589, and W 534) were also sampled in 2009 (Nystrom, 2011); two of those wells (CL 149 and W 534) were sampled as part of the 2004-05 round of the study as well (Nystrom, 2006). Three Susquehanna River Basin wells sampled in 2014 (BM 90, OG 316, and TI 892) were also sampled in 2009 (Reddy and Risen, 2012); one of those wells (BM 90) was sampled as part of the 2004-05 round of the study, as well (Hetcher-Aguila and Eckhardt, 2006). Domestic wells that are completed in sand and gravel aquifers are generally finished with open-ended casing so that groundwater enters the well only through the end of the casing (thus, the casing depth and well depth for domestic sand and gravel wells listed in table 2 are the same). Production wells, however, are typically completed with a well screen to maximize the well yield; the difference between the casing depth and the well depth in table 2 is the approximate screened interval for these wells. In some cases, however, smaller yielding production wells are completed open-ended in sand and gravel aquifers with no screen (that is, W3220). Bedrock wells, both domestic and production, are completed with a surface casing cemented several feet into competent bedrock, and the balance of the well is completed as an open hole in bedrock. In bedrock wells, groundwater moves mainly through bed partings, joints, and other fractures in the rock towards the wellbore under pumping conditions.

\section{Sampling Methods}

Water-quality samples were collected and processed in accordance with documented USGS protocols (U.S. Geological Survey, 2006). The samples were collected before any water treatment system to be representative of the native aquifer water. Samples from domestic wells were collected from a spigot near the pressure tank; samples from production wells were collected at the spigot or faucet used for collection of raw water samples by water managers.

Samples were collected from garden hose thread spigots at all sites where possible. Domestic wells were purged by pumping groundwater to waste for at least 20 minutes at pumping rates ranging from about 2 to 5 gallons per minute ( $\mathrm{gal} / \mathrm{min}$ ) or until at least one well casing volume of water had passed the sampling point. Wells that had been used recently required removal of less than three well casing 


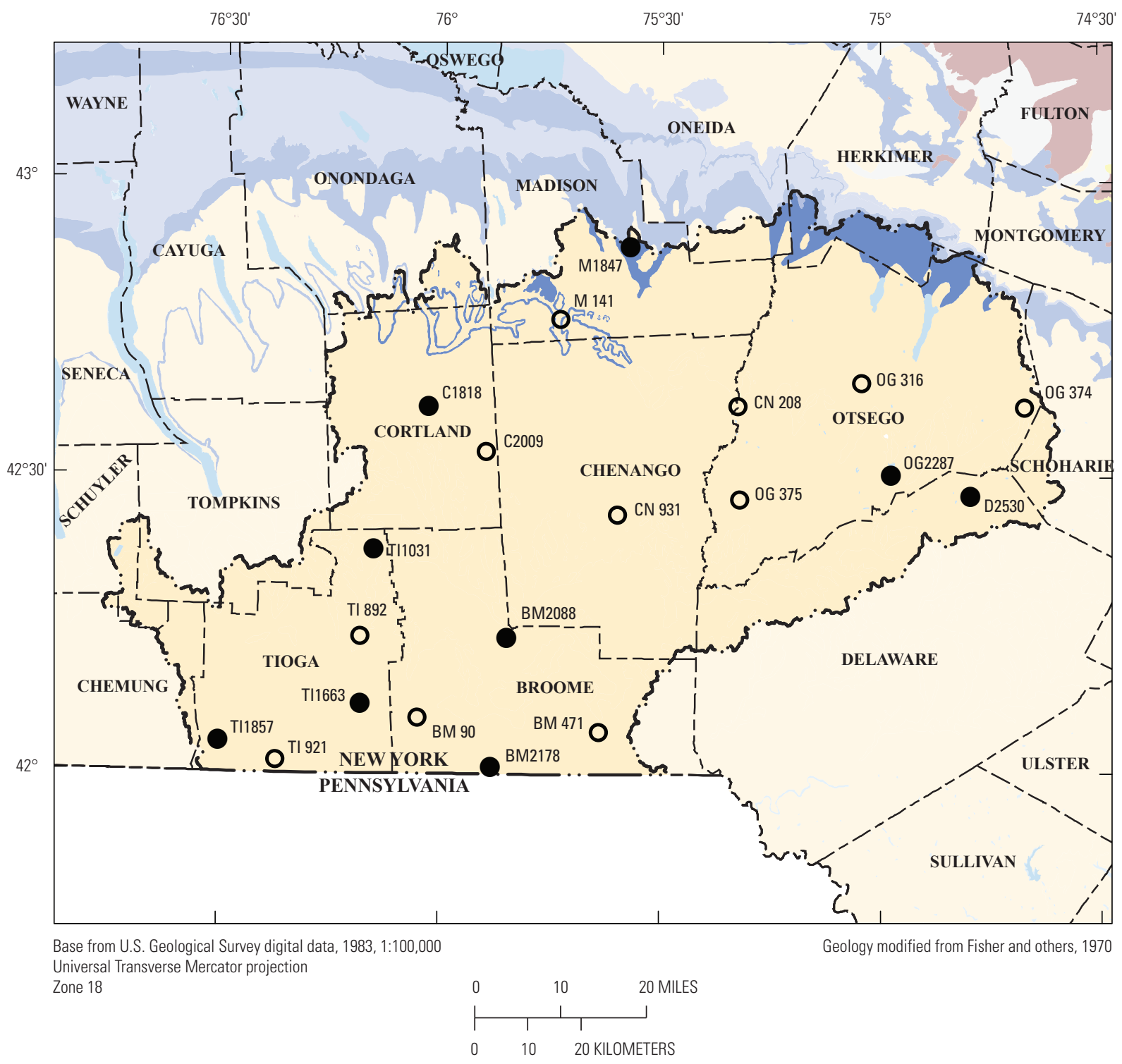

EXPLANATION

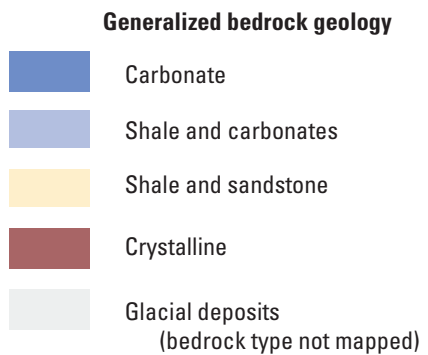

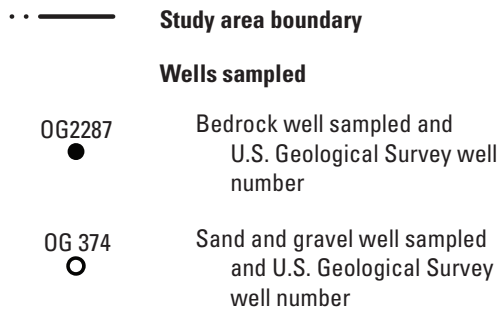

Figure 5. Generalized bedrock geology of the Susquehanna River Basin, New York, and locations of wells sampled in 2014. 


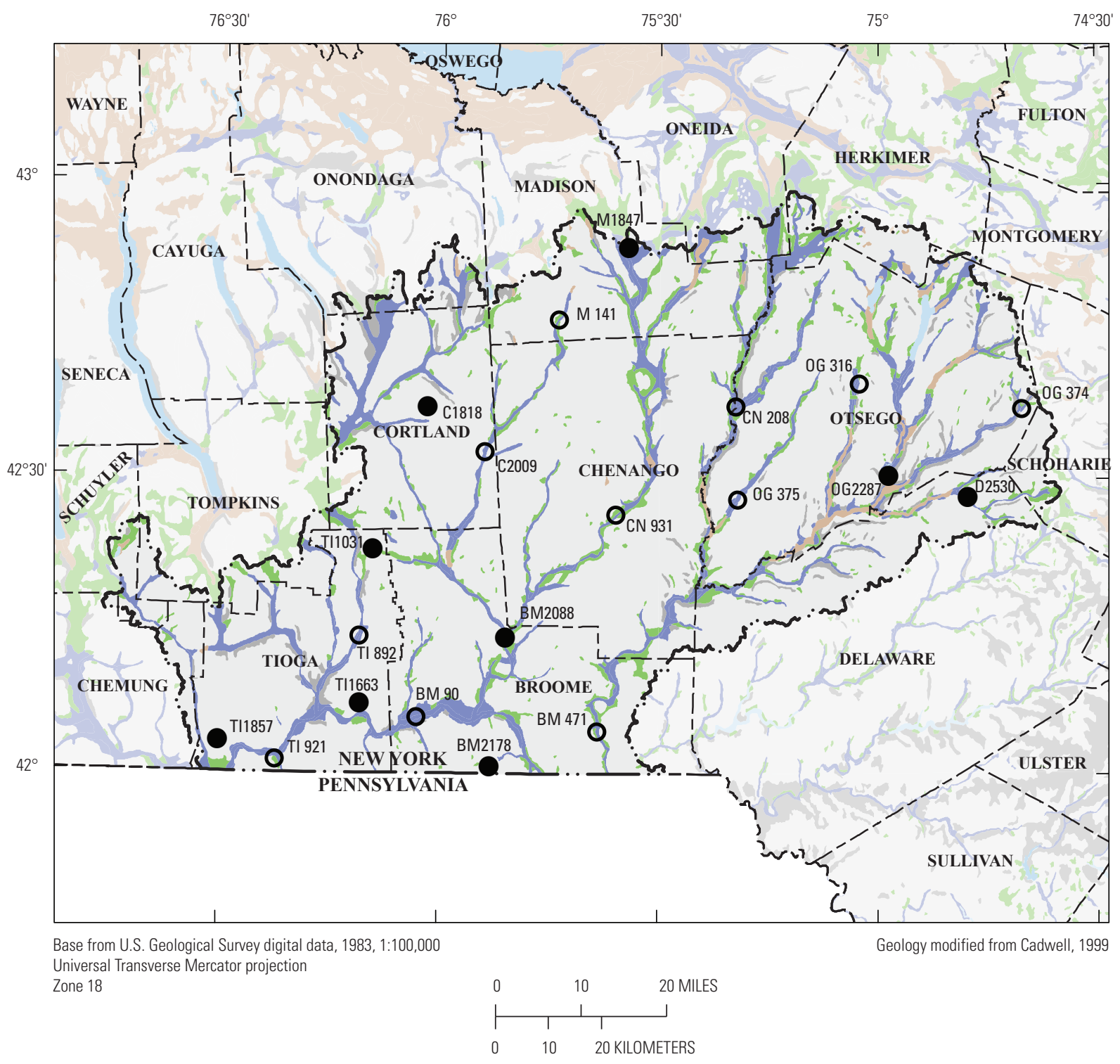

EXPLANATION

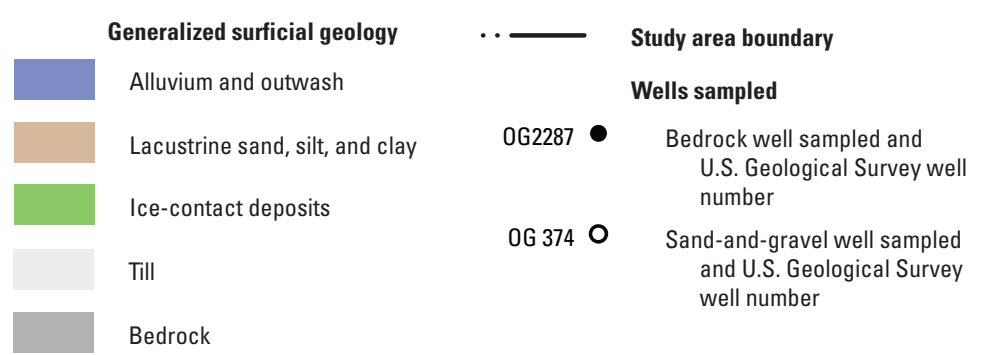

Figure 6. Generalized surficial geology of the Susquehanna River Basin, New York, and locations of wells sampled in 2014. 
Table 2. Description of wells from which water samples were collected in the Lake Champlain and Susquehanna River Basins, New York, 2014.

[-, unknown; well types: P, production; D, domestic. Land-cover categories: D, developed; F, forested; $\mathrm{A}$, agricultural; W, open water; WL, wetlands. Well locations are for the Lake Champlain Basin are shown in figures 2 and 3, and for the Susquehanna River Basin, in figures 5 and 6]

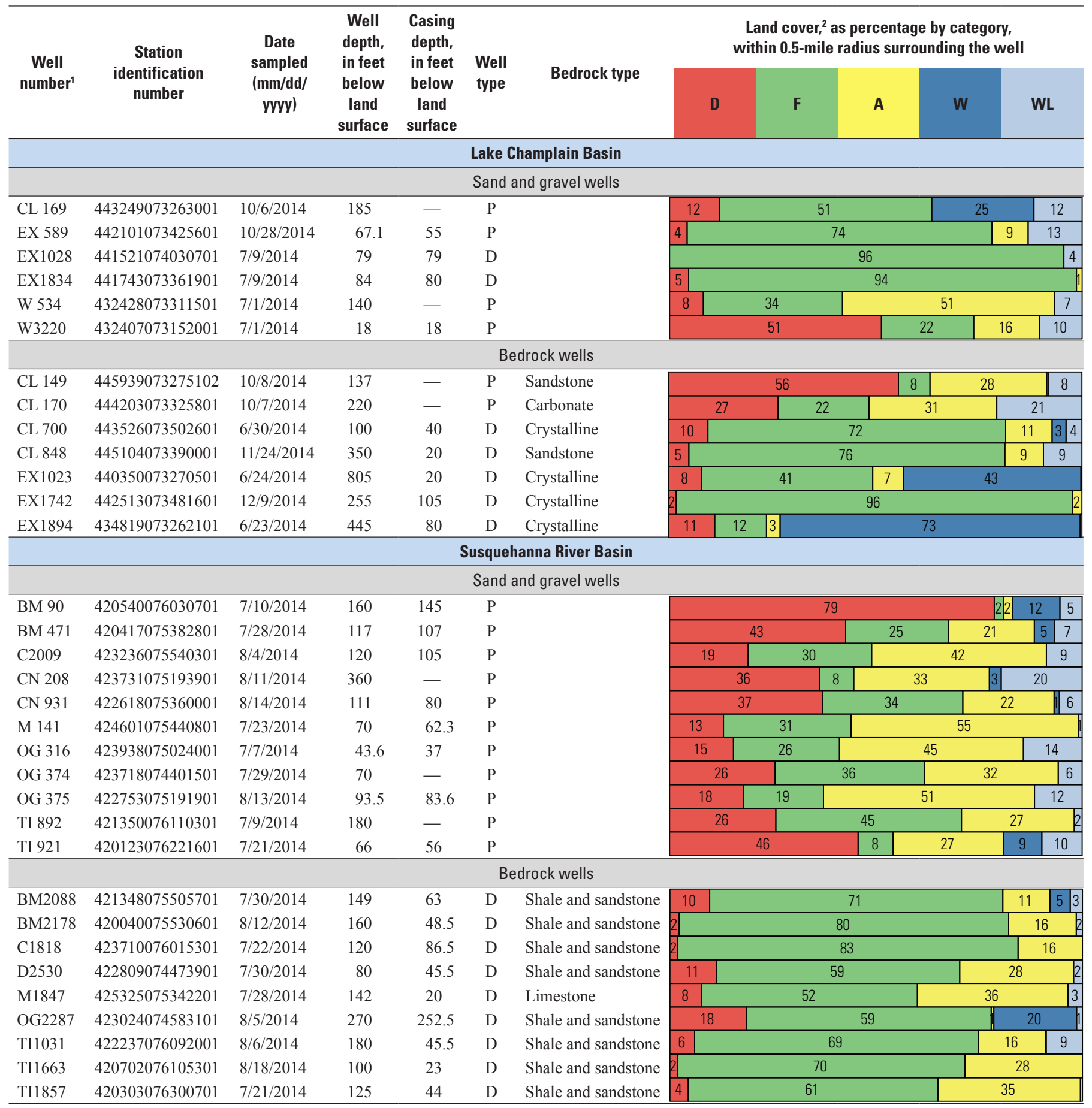

'Prefix denotes county: BM, Broome; C, Cortland; CL, Clinton; CN, Chenango; D, Delaware; EX, Essex; M, Madison; OG, Otsego; TI, Tioga; W, Washington. Number is local well identification number assigned by the U.S. Geological Survey.

${ }^{2}$ Determined from the National Land Cover Database (Vogelmann and others, 2001). 
Table 3. Summary of 33 wells from which water samples were collected in the Lake Champlain and Susquehanna River Basins, New York, 2014.

\begin{tabular}{|c|c|c|c|}
\hline \multirow{2}{*}{ Basin and type of well } & \multicolumn{3}{|c|}{ Number of wells } \\
\hline & Production & Domestic & Total \\
\hline \multicolumn{4}{|l|}{ Lake Champlain Basin } \\
\hline Wells completed in sand and gravel (depth 18 to 185 feet below land surface) & 4 & 2 & 6 \\
\hline Wells completed in bedrock (depth 100 to 805 feet below land surface) & 2 & 5 & 7 \\
\hline All well types & 6 & 7 & 13 \\
\hline \multicolumn{4}{|l|}{ Susquehanna River Basin } \\
\hline Wells completed in sand and gravel (depth 43.6 to 360 feet below land surface) & 11 & 0 & 11 \\
\hline Wells completed in bedrock (depth 80 to 270 feet below land surface) & 0 & 9 & 9 \\
\hline All well types & 11 & 9 & 20 \\
\hline All basins & 17 & 16 & 33 \\
\hline
\end{tabular}

volumes (U.S. Geological Survey, 2006). At least three well casings of water were pumped from production wells before sampling; several were pumped for 1 hour or more prior to sampling, typically at rates of about $100 \mathrm{gal} / \mathrm{min}$. During well purging, notes about the well, surrounding land, and land use were recorded, including a global positioning system measurement of latitude and longitude. Field measurements of water temperature, $\mathrm{pH}$, specific conductance, and dissolved oxygen concentration were recorded at the site using portable instruments (U.S. Geological Survey, n.d.).

The flow rate for sample collection was adjusted to less than $0.5 \mathrm{gal} / \mathrm{min}$ when possible. The sampling tube was then connected to a sample collection chamber constructed of a polyvinyl chloride frame and a clear plastic chamber bag, the purpose of which is to minimize the possibility of any airborne contaminants getting into the water samples. The tubing and spigot attachment equipment for each sample were precleaned (U.S. Geological Survey, 2006).

Samples were collected and preserved in the sampling chamber according to standard USGS procedures (U.S. Geological Survey, 2006). Samples for nutrient, major ion, and some trace element analyses were filtered through disposable (one-time use) 0.45-micrometer $(\mu \mathrm{m})$ pore-size polyether sulfone capsule filters that were preconditioned in the laboratory with 3 liters (L) of deionized water on the day of sample collection and stored on ice until use in the field. Samples for pesticide analyses were filtered through baked $0.7-\mu \mathrm{m}$ pore-size glass-fiber filters. Ultrapure nitric acid preservation was required for trace element samples, except mercury, which was preserved with ultrapure hydrochloric acid. Hydrochloric acid was added to samples analyzed for volatile organic compounds (VOCs) to reduce the sample $\mathrm{pH}$ below 2.0 and kill bacteria that might degrade VOCs. Samples for major cation analysis and some samples for radiochemical analysis were preserved with ultrapure nitric acid. Acid preservative was added after the collection of other samples to avoid the possibility of cross contamination by the acid preservative; for example, samples preserved with nitric acid were acidified after the collection of samples for nutrient analysis. Water samples for radon analysis were collected through a septum chamber with a glass syringe, according to standard USGS procedures (U.S. Geological Survey, 2006). Bottles containing water samples for the analysis of dissolved gases were filled and sealed while submerged in a beaker of well water to prevent exposure to the atmosphere. Samples for bacterial analysis were collected in accordance with NYSDEC and NYSDOH protocols (Clesceri and others, 1998), except that the tap from which each water sample was collected was not flame sterilized. Water samples for bacterial analysis were collected in sterilized bottles provided by the NYSDOH-certified analyzing laboratory. After collection, all water samples except those for radiochemical analyses were chilled to 4 degrees Celsius $\left({ }^{\circ} \mathrm{C}\right)$ or less and were kept chilled until delivery to the analyzing laboratory. Bacterial samples were hand delivered to the analyzing laboratory within 6 hours of collection; all other samples were shipped by overnight delivery to the designated laboratories.

\section{Analytical Methods}

Samples were measured for 148 physiochemical properties and constituents, including dissolved gases, major ions, nutrients, trace elements, pesticides, pesticide degradates, VOCs, radionuclides, and bacteria. Water temperature, $\mathrm{pH}$, dissolved oxygen concentration, and specific conductance were measured at the sampling site. Major ions, nutrients, total organic carbon, trace elements, radon-222, pesticides, pesticide degradates, and VOCs were analyzed at the USGS NWQL in Denver, Colorado. Selected dissolved gases were analyzed at the USGS Chlorofluorocarbon Laboratory in Reston, Virginia. Gross- $\alpha$ and gross- $\beta$ radioactivities were analyzed at Test America in Richland, Washington. Samples were analyzed for indicator bacteria at one of the following 
NYSDOH-certified laboratories: Lake Champlain Basin samples were analyzed at the Darren Freshwater Institute in Bolton Landing, N.Y.; Susquehanna River Basin samples were analyzed at Community Science Institute in Ithaca, N.Y.

Anion concentrations were measured by ion-exchange chromatography, and cation concentrations were measured by inductively coupled plasma-atomic emission spectrometry (ICP-AES), as described in Fishman (1993). Color was determined by visual comparison using method I-1250-85 (Fishman and Friedman, 1989). Nutrients were analyzed by colorimetry, as described by Fishman (1993), and Kjeldahl digestion with photometric finish, as described by Patton and Truitt (2000). Total organic carbon samples were analyzed by high temperature combustion and catalytic oxidation for measurement by infrared detection according to Standard Method 5310B (Clesceri and others, 1998). Mercury concentrations were measured through cold vapor-atomic fluorescence spectrometry according to methods described by Garbarino and Damrau (2001). Arsenic, chromium, and nickel were analyzed by use of collision/reaction cell inductively coupled plasma-mass spectrometry, as described by Garbarino and others (2006). The remaining trace elements were analyzed by ICP-AES (Struzeski and others, 1996), inductively coupled plasma-optical emission spectrometry, and inductively coupled plasma-mass spectrometry (Garbarino and Struzeski, 1998). Procedures for in-bottle digestions for trace element analyses described by Hoffman and others (1996) were followed. Radon-222 activities were measured through liquid scintillation counting (ASTM International, 2006). Samples for pesticide analyses were processed as described by Wilde and others (2004) and were analyzed using gas chromatographymass spectrometry (GC-MS) and high-performance liquid chromatography-mass spectrometry, as described by Zaugg and others (1995), Furlong and others (2001), and Sandstrom and others (2001). VOCs were analyzed by GC-MS using methods described by Connor and others (1998).

Gross- $\alpha$ and gross- $\beta$ radioactivities were measured according to EPA method 900.0 (U.S. Environmental Protection Agency, 1980). Carbon dioxide $\left(\mathrm{CO}_{2}\right)$ and methane $\left(\mathrm{CH}_{4}\right)$ concentrations were measured through gas chromatography with flame ionization detection; dissolved nitrogen gas and argon concentrations were measured using gas chromatography with thermal conductivity detection (Busenberg and others, 1998). Indicator bacteria samples were tested for total coliforms, fecal coliforms (also known as thermotolerant coliforms), and Escherichia coli (E. coli) using membrane filtration and standard method 9222; a heterotrophic plate count test (SM 9215 B) also was done (Clesceri and others, 1998).

\section{Quality-Control Samples}

In addition to the 33 groundwater samples, 2 field blank samples and 1 replicate sample were collected for quality assurance. Silica, ammonia, and ammonia plus organic nitrogen were detected in one or both field blank samples. In the field blank collected in the Lake Champlain Basin and the field blank collected in the Susquehanna River Basin, silica was measured at 0.033 milligram per liter $(\mathrm{mg} / \mathrm{L})$ and $0.045 \mathrm{mg} / \mathrm{L}$, respectively (laboratory reporting level [LRL] for silica is $0.036 \mathrm{mg} / \mathrm{L}$ ). The minimum silica concentration detected in the environmental samples was $4.02 \mathrm{mg} / \mathrm{L}$. In one field blank, collected in the Lake Champlain Basin, ammonia was measured at a concentration of $0.012 \mathrm{mg} / \mathrm{L}$ as nitrogen $(\mathrm{N}$; LRL for ammonia is $0.010 \mathrm{mg} / \mathrm{L}$ ). One environmental sample had an ammonia concentration less than $0.012 \mathrm{mg} / \mathrm{L}$ as $\mathrm{N}$. This sample was given a "V" remark code in the associated tables and discussion within the text. "V" remark codes indicate that a value may be affected by contamination; the analyte was detected in environmental samples and the associated blanks. In the Susquehanna River Basin field blank, ammonia plus organic nitrogen was measured at $0.19 \mathrm{mg} / \mathrm{L}$ as $\mathrm{N}$ (LRL for ammonia plus organic nitrogen as $\mathrm{N}$ is $0.14 \mathrm{mg} / \mathrm{L}$ ). Six environmental samples had ammonia plus organic nitrogen detections less than $0.19 \mathrm{mg} / \mathrm{L}$ as N. These six samples were given "V" remark codes in associated tables and discussion within the text. Two environmental samples collected in the Susquehanna River Basin (BM 90 and OG 316) were collected using the equipment used in the Lake Champlain Basin. Therefore, detections in these two samples were evaluated in the context of the Lake Champlain Basin field blank analysis. The ammonia plus organic nitrogen concentration of $0.10 \mathrm{mg} / \mathrm{L}$ as $\mathrm{N}$ at $\mathrm{OG} 316$ was not given a "V" code because there was no detection in the blank sample collected with the Lake Champlain Basin equipment. The variability between replicate samples was less than 20 percent for all constituents with the exception of low level gross- $\beta$ activity.

\section{Groundwater Quality}

Many of the constituents for which the groundwater samples were analyzed were not detected in any sample. Some concentrations are reported as "E" (for estimated). Estimated concentrations are typically reported when the detected value is less than the established LRL or when recovery of a compound has been shown to be highly variable (Childress and others, 1999). Concentrations of some constituents (table 4) exceeded maximum contaminant levels (MCLs) or secondary drinking-water standards (SDWS) set by the EPA (U.S. Environmental Protection Agency, 2009) or NYSDOH (New York State Department of Health, 2011) or proposed alternative MCLs set by the EPA (U.S. Environmental Protection Agency, 1999). MCLs are enforceable standards for finished water in public water supplies; they are not enforceable for private homeowner wells but are presented here as a standard for evaluation of the water-quality results. SDWS are nonenforceable drinking-water standards that typically relate to aesthetic concerns such as taste, odor, or staining of plumbing fixtures. Well owners were notified promptly if any constituent exceeded EPA or NYSDOH 
Table 4. Constituents that exceeded primary and (or) secondary drinking-water standards in groundwater samples collected in the Lake Champlain and Susquehanna River Basins, New York, 2014.

[Well locations for the Lake Champlain Basin are shown in figures 2 and 3, and for the Susquehanna River Basin, in figures 5 and 6. P, production well; D, domestic well; - , not applicable; pAMCL, proposed alternative maximum contaminant level; pMCL, proposed maximum contaminant level; f, in filtered water; $\mathrm{u}$, in unfiltered water]

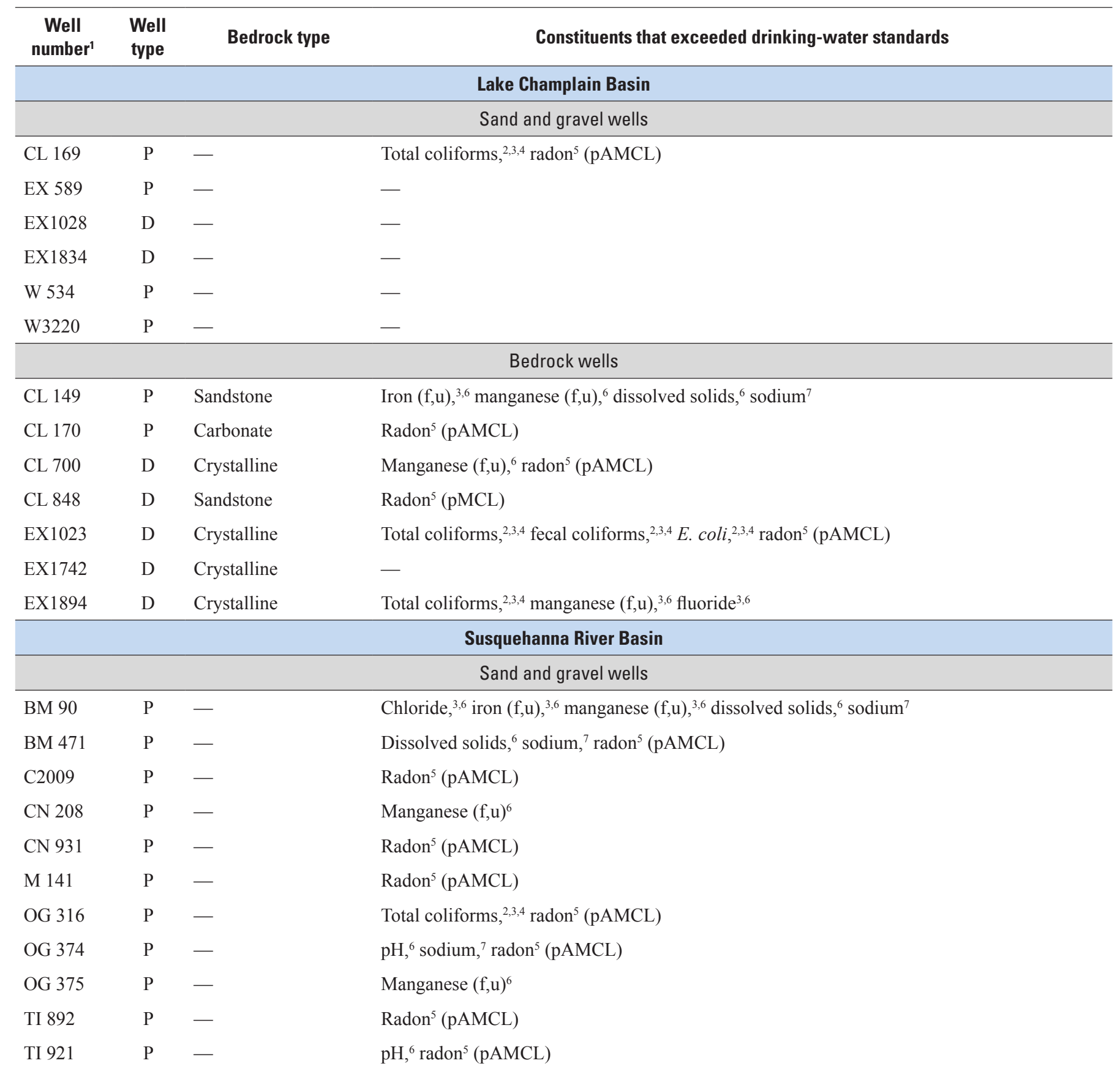


Table 4. Constituents that exceeded primary and (or) secondary drinking-water standards in groundwater samples collected in the Lake Champlain and Susquehanna River Basins, New York, 2014._Continued

[Well locations for the Lake Champlain Basin are shown in figures 2 and 3, and for the Susquehanna River Basin, in figures 5 and 6. P, production well; $\mathrm{D}$, domestic well; —, not applicable; pAMCL, proposed alternative maximum contaminant level; pMCL, proposed maximum contaminant level; f, in filtered water; u, in unfiltered water]

\begin{tabular}{|c|c|c|c|}
\hline $\begin{array}{c}\text { Well } \\
\text { number }\end{array}$ & $\begin{array}{l}\text { Well } \\
\text { type }\end{array}$ & Bedrock type & Constituents that exceeded drinking-water standards \\
\hline \multicolumn{4}{|r|}{ Susquehanna River Basin-Continued } \\
\hline BM2088 & $\mathrm{D}$ & Shale and sandstone & $\begin{array}{l}\text { Barium, }{ }^{2,3} \text { chloride }{ }^{3,6} \text { iron }(\mathrm{f}, \mathrm{u}),{ }^{3,6} \text { manganese }(\mathrm{f}, \mathrm{u}),{ }^{3,6} \text { dissolved solids, }{ }^{6} \text { gross- } \alpha \text { radioactivity },{ }^{2,3} \\
\quad \text { sodium, }{ }^{7} \text { methane }{ }^{8}\end{array}$ \\
\hline C1818 & $\mathrm{D}$ & Shale and sandstone & Sodium, ${ }^{7} \operatorname{radon}^{5}$ (pAMCL) \\
\hline D2530 & $\mathrm{D}$ & Shale and sandstone & $\operatorname{Radon}^{5}$ (pAMCL) \\
\hline M1847 & $\mathrm{D}$ & Limestone & Total coliforms, ${ }^{2,3,4} \operatorname{radon}^{5}$ (pAMCL) \\
\hline OG2287 & $\mathrm{D}$ & Shale and sandstone & Manganese $(\mathrm{f}, \mathrm{u})^{6}$ \\
\hline
\end{tabular}

${ }^{1}$ Prefix denotes county: BM, Broome; C, Cortland; CL, Clinton; CN, Chenango; D, Delaware; EX, Essex; M, Madison; OG, Otsego; TI, Tioga; W, Washington. Number is local well identification number assigned by the U.S. Geological Survey.

${ }^{2}$ U.S. Environmental Protection Agency (2009) maximum contaminant level.

${ }^{3}$ New York State Department of Health (2011) maximum contaminant level.

${ }^{4}$ Maximum contaminant level exceedances for bacteria in public drinking-water supplies are generally defined in terms of a certain number of positive samples per month on the basis of the number of samples collected.

${ }^{5}$ U.S. Environmental Protection Agency (1999) proposed maximum contaminant level of 300 picocuries per liter for areas that do not implement an indoor air radon mitigation program.

${ }^{6}$ U.S. Environmental Protection Agency (2009) secondary drinking-water standard.

${ }^{7}$ U.S. Environmental Protection Agency (2009) drinking-water advisory taste threshold.

${ }^{8}$ Methane concentration above recommended monitoring concentration (Eltschlager and others, 2001). 
MCLs. Copies of the complete analytical results were mailed to each well owner.

The results of analyses of the 33 groundwater samples collected in the Lake Champlain Basin and Susquehanna River Basin collected during June through December 2014 are presented in tables $1-1$ through $1-9$. Of the 148 constituents and physiochemical properties analyzed for, 75 were not detected at levels greater than the LRLs in any sample (table 1-1). Results for the remaining 73 constituents and properties that were detected in the Lake Champlain Basin and Susquehanna River Basin are presented in tables 1-2 through 1-9.

\section{Physiochemical Properties}

Groundwater-quality samples were analyzed in the field for physiochemical properties, including water temperature, $\mathrm{pH}$, specific conductance, and dissolved oxygen. Samples were collected for analysis of color. Qualitative assessment of the presence of hydrogen sulfide was noted. Results of analyses are reported in table 5 and in table 1-2. The number of samples that exceeded drinking-water standards for physiochemical properties are reported in table 6. No drinking-water standards exist for specific conductance, water temperature, and dissolved oxygen.

Most samples from the Lake Champlain Basin had a color of less than $(<) 1$ platinum-cobalt (Pt-Co) unit (tables 5, 6 , and 1-2). Three samples, two from sand and gravel wells (W 534, W3220) and one from a bedrock well (CL 149) had color of 2 Pt-Co units. One sample from a bedrock well (CL 700) had color of 8 Pt-Co units (EPA SDWS is 15 Pt-Co units). Sample $\mathrm{pH}$ was typically near neutral (median of 7.8 for sand and gravel wells, median of 7.6 for bedrock wells) and ranged from 6.7 to 8.3 . Specific conductance ranged from 70 to 1,220 microsiemens per centimeter at 25 degrees Celsius $\left(\mu \mathrm{S} / \mathrm{cm}\right.$ at $\left.25^{\circ} \mathrm{C}\right)$; the median specific conductance was $190 \mu \mathrm{S} / \mathrm{cm}$ at $25^{\circ} \mathrm{C}$ for sand and gravel wells and $390 \mu \mathrm{S} / \mathrm{cm}$ at $25^{\circ} \mathrm{C}$ for bedrock wells. Water temperature ranged from 7.5 to $16.4{ }^{\circ} \mathrm{C}$; the median temperature was $8.6^{\circ} \mathrm{C}$ for sand and gravel wells and $9.7^{\circ} \mathrm{C}$ for bedrock wells. Hydrogen sulfide odor was not detected in any wells sampled in the Lake Champlain Basin.

Most samples from the Susquehanna River Basin had a detectable color (tables 5 and 1-2). Six samples, mostly from bedrock wells had colors of 5 Pt-Co units, one sample from a bedrock well (TI1031) had a color of 12 Pt-Co units. Sample $\mathrm{pH}$ was typically near neutral (median of 7.3 for sand and gravel wells, median of 7.6 for bedrock wells) and ranged from 6.3 to 8.4. The $\mathrm{pH}$ values for samples from sand and gravel wells OG 374 and TI 921 (6.4 and 6.3, respectively) were lower than the EPA SDWS range for $\mathrm{pH}$. Specific conductance ranged from 199 to $7,980 \mu \mathrm{S} / \mathrm{cm}$ at $25^{\circ} \mathrm{C}$; the median specific conductance was $484 \mu \mathrm{S} / \mathrm{cm}$ at $25{ }^{\circ} \mathrm{C}$ for sand and gravel wells and $312 \mu \mathrm{S} / \mathrm{cm}$ at $25^{\circ} \mathrm{C}$ for bedrock wells. Water temperature ranged from 9.1 to $16.1^{\circ} \mathrm{C}$; the median temperature was $11.3^{\circ} \mathrm{C}$ for sand and gravel wells and $12.7^{\circ} \mathrm{C}$ for bedrock wells. Hydrogen sulfide odor was detected in two sand and gravel wells (CN 208, OG 316) and one bedrock well (D2530).

\section{Dissolved Gases}

Dissolved oxygen was measured in the field. Groundwater-quality samples were analyzed for dissolved gases including $\mathrm{CO}_{2}$, argon, nitrogen, and $\mathrm{CH}_{4}$. Results are reported in tables 5 and 1-2. The concentrations of $\mathrm{CO}_{2}$, argon, nitrogen gas, and $\mathrm{CH}_{4}$ were determined twice for each site; therefore, the statistics given include two samples per well. These data are listed in table 1-2. No drinking-water standards exist for $\mathrm{CO}_{2}$, argon, and nitrogen gas; however, the number of samples that exceeded drinking-water standards for $\mathrm{CH}_{4}$ are reported in table 6 .

In the Lake Champlain Basin, dissolved oxygen concentrations ranged from $<0.3$ to $11.2 \mathrm{mg} / \mathrm{L}$ (tables 5 and $1-2$ ) and typically were greater in samples from sand and gravel wells (median $5.8 \mathrm{mg} / \mathrm{L}$ ) than in samples from bedrock wells (median $0.6 \mathrm{mg} / \mathrm{L}$ ). Median concentrations of dissolved gases in samples from sand and gravel wells were $21.24 \mathrm{mg} / \mathrm{L}$ for nitrogen, $2.4 \mathrm{mg} / \mathrm{L}$ for $\mathrm{CO}_{2}, 0.756 \mathrm{mg} / \mathrm{L}$ for argon, and $<0.001 \mathrm{mg} / \mathrm{L}$ for $\mathrm{CH}_{4}$. Median concentrations of dissolved gases in samples from bedrock wells were $25.55 \mathrm{mg} / \mathrm{L}$ for nitrogen, $6.9 \mathrm{mg} / \mathrm{L}$ for $\mathrm{CO}_{2}, 0.824 \mathrm{mg} / \mathrm{L}$ for argon, and $<0.001 \mathrm{mg} / \mathrm{L}$ for $\mathrm{CH}_{4}$.

In the Susquehanna River Basin, dissolved oxygen concentrations ranged from $<0.3$ to $5.9 \mathrm{mg} / \mathrm{L}$ (tables 5 and 1-2) and, similar to the Lake Champlain Basin were typically greater in samples from sand and gravel wells (median $3.1 \mathrm{mg} / \mathrm{L}$ ) than in samples from bedrock wells (median $0.5 \mathrm{mg} / \mathrm{L}$ ). Median concentrations of dissolved gases in samples from sand and gravel wells were $20.70 \mathrm{mg} / \mathrm{L}$ for nitrogen, $21.3 \mathrm{mg} / \mathrm{L}$ for $\mathrm{CO}_{2}, 0.738 \mathrm{mg} / \mathrm{L}$ for argon, and $<0.001 \mathrm{mg} / \mathrm{L}$ for $\mathrm{CH}_{4}$. Median concentrations of dissolved gases in samples from bedrock wells were $23.20 \mathrm{mg} / \mathrm{L}$ for nitrogen, $5.2 \mathrm{mg} / \mathrm{L}$ for $\mathrm{CO}_{2}, 0.812 \mathrm{mg} / \mathrm{L}$ for argon, and $0.017 \mathrm{mg} / \mathrm{L}$ for $\mathrm{CH}_{4}$, which was detected in 9 of the 20 samples; six of those detections were at trace level. Although the EPA and NYSDOH do not have MCLs for $\mathrm{CH}_{4}$, dissolved $\mathrm{CH}_{4}$ concentrations greater than $28 \mathrm{mg} / \mathrm{L}$ can pose explosion hazards as a result of $\mathrm{CH}_{4}$ accumulation in confined spaces. The U.S. Department of Interior, Office of Surface Mining recommends that $\mathrm{CH}_{4}$ concentrations ranging from 10 to $28 \mathrm{mg} / \mathrm{L}$ in water signify an action level where the situation should be closely monitored; if the concentration increases, enclosed areas should be vented to prevent $\mathrm{CH}_{4}$ gas buildup (Eltschlager and others, 2001). The concentrations of $\mathrm{CH}_{4}$ in the two duplicate samples from bedrock well BM2088 were $61.0 \mathrm{mg} / \mathrm{L}$ and $50.5 \mathrm{mg} / \mathrm{L}$, both of which were greater than safety threshold of $28 \mathrm{mg} / \mathrm{L}$. Samples from two bedrock wells (C1818 and D2530) had concentrations of $\mathrm{CH}_{4}$ ranging from 6.52 to $11.9 \mathrm{mg} / \mathrm{L}$ (tables 6 and $1-2$ ), which exceeded the action level of 10 to $28 \mathrm{mg} / \mathrm{L}$. 


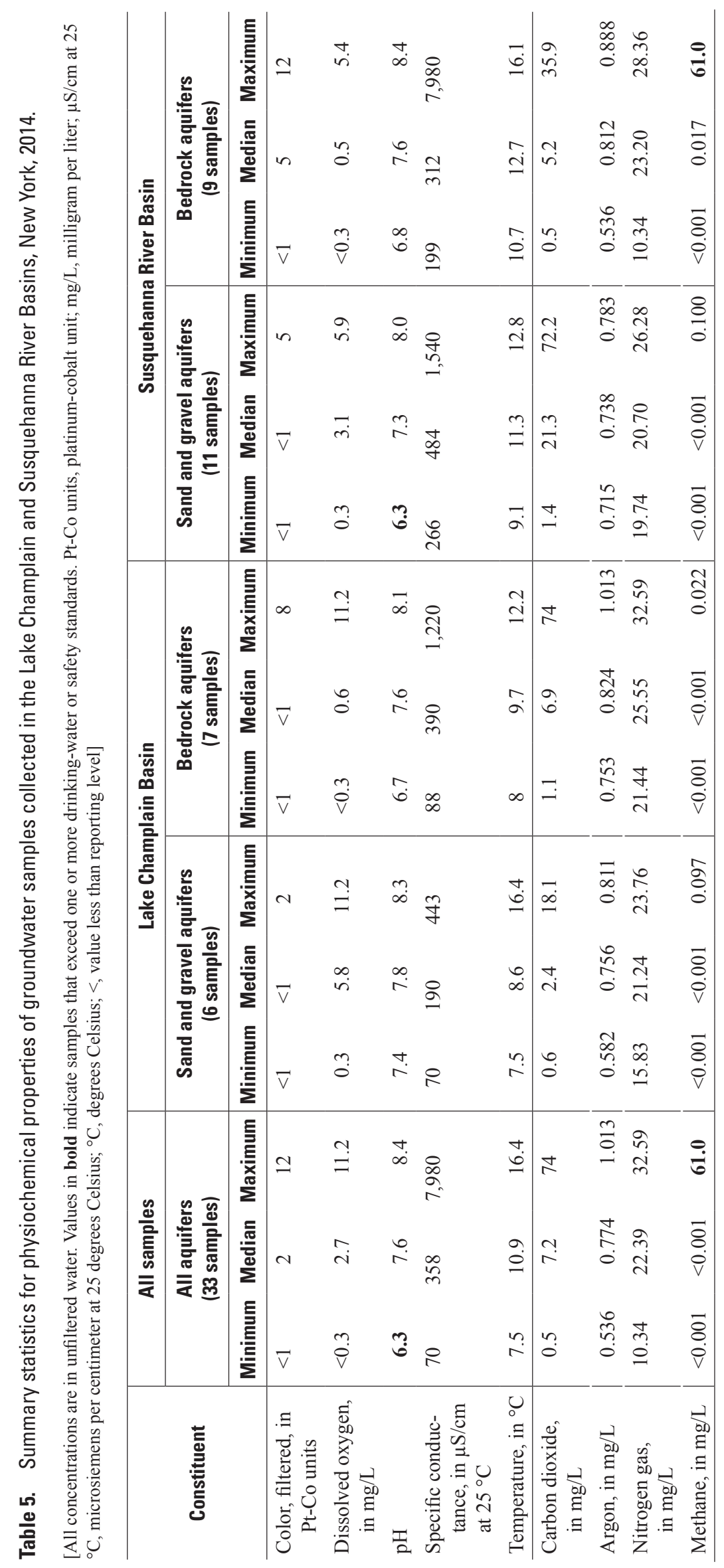


Table 6. Drinking-water standards for physiochemical properties and dissolved gases and number of groundwater samples exceeding those standards collected in the Lake Champlain and Susquehanna River Basins, New York, 2014.

[All concentrations in unfiltered water. Pt-Co units, platinum-cobalt unit; mg/L, milligram per liter]

\begin{tabular}{l|c|c|cc}
\hline \multirow{2}{*}{ Constituent } & \multirow{2}{*}{$\begin{array}{c}\text { Drinking-water } \\
\text { standard }\end{array}$} & \multicolumn{2}{|c}{ Number of samples exceeding drinking-water standards } \\
\cline { 3 - 5 } & $\begin{array}{c}\text { All samples } \\
\text { (33 samples) }\end{array}$ & $\begin{array}{c}\text { Lake Champlain Basin } \\
\text { (13 samples) }\end{array}$ & $\begin{array}{c}\text { Susquehanna River Basin } \\
\text { (20 samples) }\end{array}$ \\
\hline Color, filtered, in Pt-Co units & ${ }^{1} 15$ & 0 & 0 & 0 \\
$\mathrm{pH}$ & ${ }^{1} 6.5-8.5$ & 2 & 0 & 2 \\
Methane, in mg/L & 228 & 1 & 0 & 1 \\
\hline
\end{tabular}

${ }^{1}$ U.S. Environmental Protection Agency (2009) secondary drinking water standard.

${ }^{2}$ Methane recommended monitoring concentration (Eltschlager and others, 2001).

\section{Major Ions and Dissolved Solids}

Groundwater-quality samples were analyzed for anions, including bicarbonate, chloride, fluoride, silica, and sulfate; cations including calcium, magnesium, potassium, and sodium; alkalinity; hardness; and dissolved solids. Results are reported in tables 7 and 1-3. The number of samples that exceeded drinking-water standards for major ions and dissolved solids are reported in table 8 . No drinkingwater standards exist for calcium, magnesium, potassium, bicarbonate, silica, hardness, or alkalinity.

In the Lake Champlain Basin, the anions detected in the highest concentrations were bicarbonate (median concentration $100 \mathrm{mg} / \mathrm{L}$ in sand and gravel wells, $128 \mathrm{mg} / \mathrm{L}$ in bedrock wells) and sulfate (median concentration $8.20 \mathrm{mg} / \mathrm{L}$ in sand and gravel wells, $14.7 \mathrm{mg} / \mathrm{L}$ in bedrock wells; tables 7 and 1-3). The cations detected in the highest concentrations were calcium (median concentration $20.2 \mathrm{mg} / \mathrm{L}$ in sand and gravel wells, $36.0 \mathrm{mg} / \mathrm{L}$ in bedrock wells), magnesium (median concentration $5.46 \mathrm{mg} / \mathrm{L}$ in sand and gravel wells, $9.46 \mathrm{mg} / \mathrm{L}$ in bedrock wells), and sodium (median concentration $3.69 \mathrm{mg} / \mathrm{L}$ in sand and gravel wells, $8.57 \mathrm{mg} / \mathrm{L}$ in bedrock wells). The concentration of sodium in one sample (CL 149, $138 \mathrm{mg} / \mathrm{L}$ ) exceeded the EPA drinking water advisory taste threshold of $60 \mathrm{mg} / \mathrm{L}$; the concentration of fluoride in one sample (EX1894, $2.26 \mathrm{mg} / \mathrm{L}$ ) exceeded the NYSDOH MCL of $2.2 \mathrm{mg} / \mathrm{L}$ and the EPA secondary drinking water standard of $2.0 \mathrm{mg} / \mathrm{L}$. The concentrations of chloride and sulfate did not exceed established MCLs in any sample (tables 8 and 1-3).

For samples in the Lake Champlain Basin, three samples were classified as "soft" ( 0 to $60 \mathrm{mg} / \mathrm{L}$ as calcium carbonate, $\left.\left[\mathrm{CaCO}_{3}\right]\right)$, five as "moderately hard" (61 to $120 \mathrm{mg} / \mathrm{L}$ as $\mathrm{CaCO}_{3}$ ), two as "hard" (121 to $180 \mathrm{mg} / \mathrm{L}$ as $\mathrm{CaCO}_{3}$ ) and three as "very hard" (greater than $180 \mathrm{mg} / \mathrm{L}$ as $\mathrm{CaCO}_{3} ; \mathrm{Hem}, 1985$ ). The median hardness was $84.8 \mathrm{mg} / \mathrm{L}$ as $\mathrm{CaCO}_{3}$ for sand and gravel wells, and $142 \mathrm{mg} / \mathrm{L}$ as $\mathrm{CaCO}_{3}$ for bedrock wells; the maximum hardness was $321 \mathrm{mg} / \mathrm{L}$ as $\mathrm{CaCO}_{3}$ (bedrock well, CL 149; table 1-3). Alkalinity ranged from 24 to $283 \mathrm{mg} / \mathrm{L}$ as $\mathrm{CaCO}_{3}$; the median was $82 \mathrm{mg} / \mathrm{L}$ as $\mathrm{CaCO}_{3}$ for sand and gravel wells, and $107 \mathrm{mg} / \mathrm{L}$ as $\mathrm{CaCO}_{3}$ for bedrock wells. Dissolved solids concentrations ranged from 50 to $659 \mathrm{mg} / \mathrm{L}$ with a median of $116 \mathrm{mg} / \mathrm{L}$ for sand and gravel wells and $195 \mathrm{mg} / \mathrm{L}$ for bedrock wells. Dissolved solids concentration in one bedrock sample (CL 149, $659 \mathrm{mg} / \mathrm{L}$ ) exceeded the EPA SDWS for total dissolved solids of $500 \mathrm{mg} / \mathrm{L}$ (tables 8 and 1-3).

In the Susquehanna River Basin, the anions detected with the highest concentrations were bicarbonate (median concentration $113 \mathrm{mg} / \mathrm{L}$ in sand and gravel wells, $119 \mathrm{mg} / \mathrm{L}$ in bedrock wells), and chloride (median concentration $59.2 \mathrm{mg} / \mathrm{L}$ in sand and gravel wells, $4.15 \mathrm{mg} / \mathrm{L}$ in bedrock wells; tables 7 and 1-3). The cations detected in the highest concentrations were calcium (median concentration $46.1 \mathrm{mg} / \mathrm{L}$ in sand and gravel wells, $30.2 \mathrm{mg} / \mathrm{L}$ in bedrock wells) and sodium (median concentration $30.5 \mathrm{mg} / \mathrm{L}$ in sand and gravel wells, $17.0 \mathrm{mg} / \mathrm{L}$ in bedrock wells). The concentration of sodium in 3 sand and gravel samples (BM 90, $103 \mathrm{mg} / \mathrm{L} ; \mathrm{BM} 471$, $91.0 \mathrm{mg} / \mathrm{L}$, and $\mathrm{OG} \mathrm{374,} 64.7 \mathrm{mg} / \mathrm{L}$ ) and 2 bedrock samples (BM2088, 1,200 mg/L; and C1818, $80.6 \mathrm{mg} / \mathrm{L}$ ) exceeded the EPA drinking water advisory taste threshold of $60 \mathrm{mg} / \mathrm{L}$. The concentration of chloride in 1 sand and gravel sample (BM 90, $312 \mathrm{mg} / \mathrm{L}$ ) and 1 bedrock sample (BM2088, 2,260 mg/L) exceeded the EPA MCL and the NYSDOH MCL of $250 \mathrm{mg} / \mathrm{L}$. The concentrations of fluoride and sulfate did not exceed established MCLs in any sample (tables 8 and 1-3).

For samples in the Susquehanna River Basin, two samples were classified as "soft," seven as "moderately hard," six as "hard," and five as "very hard." The median hardness was $149 \mathrm{mg} / \mathrm{L}$ as $\mathrm{CaCO}_{3}$ for sand and gravel wells and $100 \mathrm{mg} / \mathrm{L}$ as $\mathrm{CaCO}_{3}$ for bedrock wells; and the maximum hardness was $794 \mathrm{mg} / \mathrm{L}$ as $\mathrm{CaCO}_{3}$. Alkalinity ranged from 22 to $295 \mathrm{mg} / \mathrm{L}$ as $\mathrm{CaCO}_{3}$; the median was $92 \mathrm{mg} / \mathrm{L}$ as $\mathrm{CaCO}_{3}$ for sand and gravel wells, and $100 \mathrm{mg} / \mathrm{L}$ as $\mathrm{CaCO}_{3}$ for bedrock wells. Dissolved solids concentrations ranged from 112 to $4,550 \mathrm{mg} / \mathrm{L}$ with a median of $278 \mathrm{mg} / \mathrm{L}$ for sand and gravel wells and $176 \mathrm{mg} / \mathrm{L}$ for bedrock wells. Dissolved solids concentration in two sand and gravel wells (BM 90, $1,080 \mathrm{mg} / \mathrm{L} ; \mathrm{BM} 471,628 \mathrm{mg} / \mathrm{L}$ ) and one bedrock sample (BM2088, 4,550 $\mathrm{mg} / \mathrm{L}$ ) exceeded the EPA SDWS for total dissolved solids of $500 \mathrm{mg} / \mathrm{L}$ (tables 8 and 1-3). 


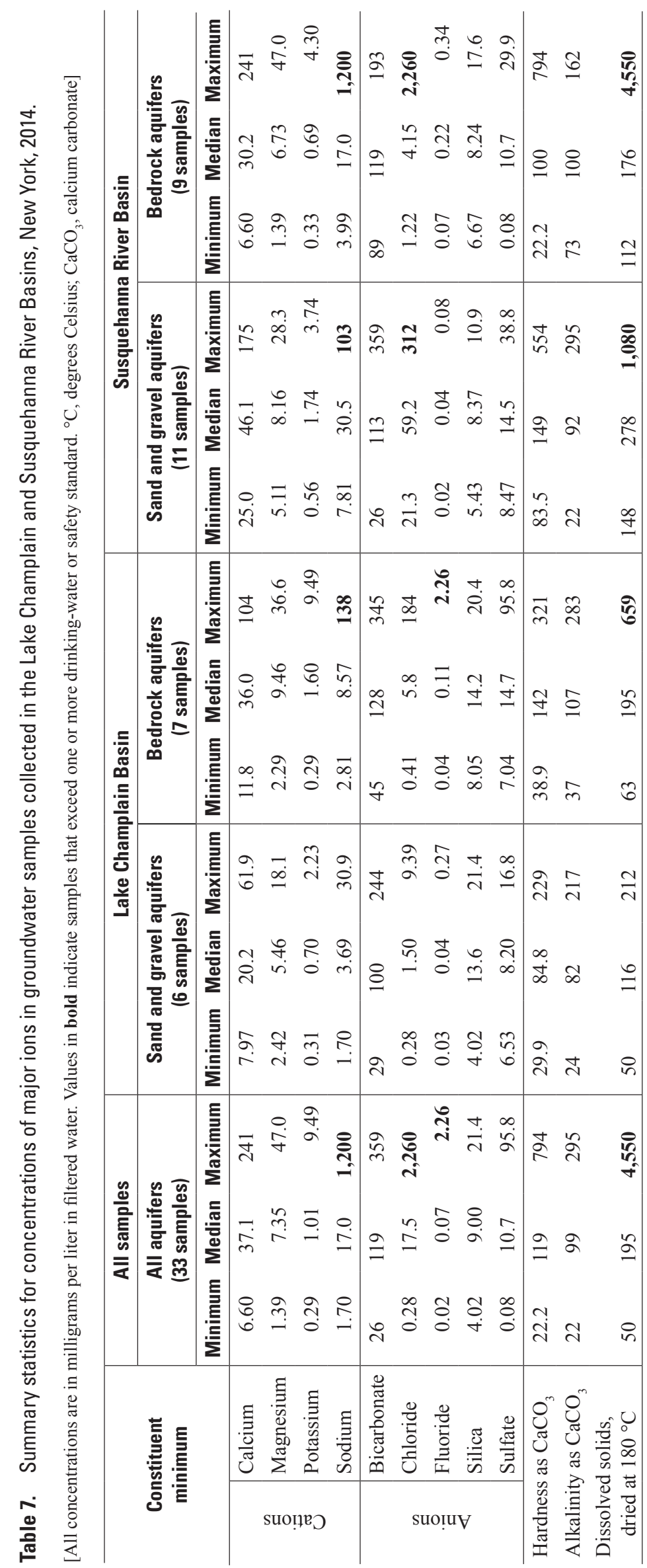


Table 8. Drinking-water standards for concentrations of major ions and number of groundwater samples exceeding those standards collected in the Lake Champlain and Susquehanna River Basins, New York, 2014.

[All concentrations are in milligrams per liter in filtered water. ${ }^{\circ} \mathrm{C}$, degrees Celsius]

\begin{tabular}{|c|c|c|c|c|c|}
\hline \multirow{2}{*}{\multicolumn{2}{|c|}{ Constituent }} & \multirow{3}{*}{$\begin{array}{c}\begin{array}{c}\text { Drinking-water } \\
\text { standard }\end{array} \\
\\
{ }^{1} 60\end{array}$} & \multicolumn{3}{|c|}{ Number of samples exceeding drinking-water standards } \\
\hline & & & \multirow{2}{*}{$\begin{array}{c}\text { All samples } \\
\text { (33 samples) }\end{array}$} & \multirow{2}{*}{$\begin{array}{c}\text { Lake Champlain } \\
\text { Basin } \\
\text { (13 samples) } \\
1 \\
1\end{array}$} & \multirow{2}{*}{$\begin{array}{c}\text { Susquehanna River } \\
\text { Basin } \\
\text { (20 samples) } \\
\\
5\end{array}$} \\
\hline 营 & Sodium & & & & \\
\hline \multirow{5}{*}{ 泀 } & Chloride & 2,3250 & 2 & 0 & 2 \\
\hline & Fluoride & ${ }^{4} 4.0$ & 0 & 0 & 0 \\
\hline & & 22.2 & 1 & 1 & 0 \\
\hline & & ${ }^{3} 2$ & 1 & 1 & 0 \\
\hline & Sulfate & 2,3250 & 0 & 0 & 0 \\
\hline \multicolumn{2}{|c|}{ Dissolved solids, dried at $180^{\circ} \mathrm{C}$} & ${ }^{3} 500$ & 4 & 1 & 3 \\
\hline
\end{tabular}

${ }^{1}$ U.S. Environmental Protection Agency (2009) drinking water advisory taste threshold.

${ }^{2}$ New York State Department of Health (2011) maximum contaminant level.

${ }^{3}$ U.S. Environmental Protection Agency (2009) secondary drinking water standard.

${ }^{4}$ U.S. Environmental Protection Agency (2009) maximum contaminant level.

\section{Nutrients and Total Organic Carbon}

Groundwater-quality samples were analyzed for several nutrients, including ammonia plus organic nitrogen, ammonia, nitrate plus nitrite, nitrate, nitrite, and orthophosphate, as well as total organic carbon. Results are reported in tables 9 and $1-4$. The number of samples that exceeded drinkingwater standards for nitrate, nitrite, and nitrate plus nitrite are reported in table 10. No drinking-water standards exist for ammonia, orthophosphate, and total organic carbon.

The dominant nutrient detected in the Lake Champlain Basin was nitrate (tables 9 and 1-4). The concentrations of nitrate ranged from $<0.039$ to $1.58 \mathrm{mg} / \mathrm{L}$ as nitrogen $(\mathrm{N})$ and were generally greater in samples from sand and gravel wells (median $0.482 \mathrm{mg} / \mathrm{L}$ as $\mathrm{N}$ ) than in samples from bedrock wells (median $0.063 \mathrm{mg} / \mathrm{L}$ as $\mathrm{N}$ ). The concentrations of nitrate and nitrate plus nitrite did not exceed the NYSDOH and EPA MCL of $10 \mathrm{mg} / \mathrm{L}$ as $\mathrm{N}$ in any sample (tables 10 and $1-4$ ). The concentrations of ammonia ranged from $<0.010$ to $0.06 \mathrm{mg} / \mathrm{L}$ as nitrogen $(\mathrm{N})$ and were similar in samples from sand and gravel wells and in samples from bedrock wells. Nitrite was detected in only 3 of 13 samples and did not exceed the NYSDOH and EPA MCL of $1 \mathrm{mg} / \mathrm{L}$ as $\mathrm{N}$ in any sample. Orthophosphate concentrations ranged from $<0.004$ to $0.109 \mathrm{mg} / \mathrm{L}$ as phosphorus (P). Total organic carbon was detected in 4 of the 13 samples; the maximum concentration was $1.8 \mathrm{mg} / \mathrm{L}$.

The dominant nutrient detected in the Susquehanna River Basin was nitrate (tables 9 and 1-4). The concentration of nitrate ranged from $<0.040$ to $4.58 \mathrm{mg} / \mathrm{L}$ as $\mathrm{N}$ and was generally greater in samples from sand and gravel wells (median $1.44 \mathrm{mg} / \mathrm{L}$ as $\mathrm{N}$ ) than in samples from bedrock wells (median $<0.040 \mathrm{mg} / \mathrm{L}$ as $\mathrm{N}$ ). The concentration of nitrate and nitrate plus nitrite did not exceed the NYSDOH and EPA MCL of $10 \mathrm{mg} / \mathrm{L}$ as $\mathrm{N}$ in any sample (tables 10 and 1-4). The concentration of ammonia ranged from $<0.010$ to $1.40 \mathrm{mg} / \mathrm{L}$ as $\mathrm{N}$ and was generally higher in samples from bedrock wells (median $0.052 \mathrm{mg} / \mathrm{L}$ as $\mathrm{N}$ ) than in samples from sand and gravel wells (median $<0.010 \mathrm{mg} / \mathrm{L}$ as $\mathrm{N}$ ). Nitrite was detected in 6 of the 20 samples and did not exceed the NYSDOH and EPA MCL of $1 \mathrm{mg} / \mathrm{L}$ as $\mathrm{N}$ in any sample. Orthophosphate concentrations ranged from $<0.004$ to $0.127 \mathrm{mg} / \mathrm{L}$ as phosphorus (P). Total organic carbon was detected in 5 of the 20 samples; the maximum concentration was $1.2 \mathrm{mg} / \mathrm{L}$.

\section{Trace Elements}

Twenty-five trace elements were analyzed for in filtered and (or) unfiltered groundwater-quality samples. Results are reported in tables 11 and $1-5$. The number of samples that exceeded drinking-water standards for trace elements are reported in table 12. No drinking-water standards exist for boron, cobalt, lithium, molybdenum, nickel, and strontium.

In the Lake Champlain Basin, the trace elements present in the highest median concentrations in the samples were strontium (median 94.2 micrograms per liter $[\mu \mathrm{g} / \mathrm{L}]$ in sand and gravel wells; median $437 \mu \mathrm{g} / \mathrm{L}$ in bedrock wells), iron (median $51.8 \mu \mathrm{g} / \mathrm{L}$ in unfiltered water from bedrock wells; 


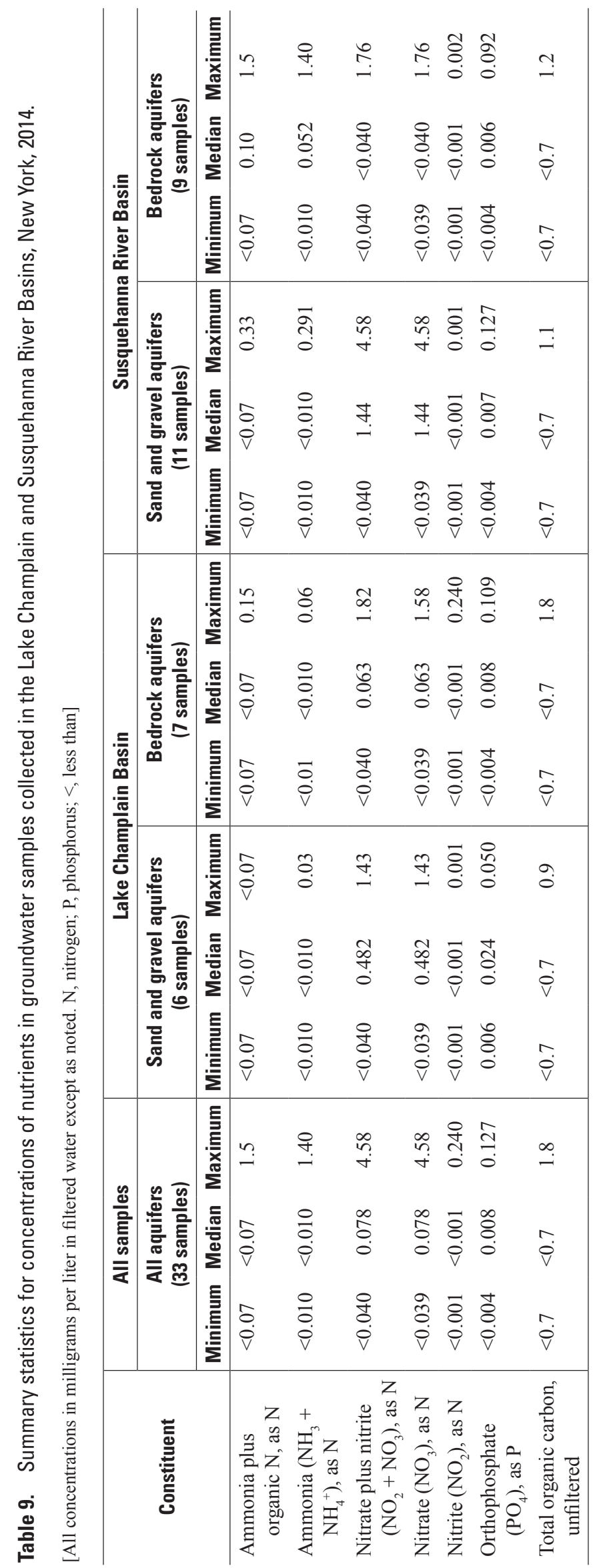


Table 10. Drinking-water standards for concentrations of nutrients and number of groundwater samples exceeding those standards collected in the Lake Champlain and Susquehanna River Basins, New York, 2014.

[All concentrations in milligrams per liter in filtered water. N, nitrogen]

\begin{tabular}{|c|c|c|c|c|}
\hline \multirow[b]{2}{*}{ Constituent } & \multirow{2}{*}{$\begin{array}{l}\text { Drinking-water } \\
\text { standard }\end{array}$} & \multicolumn{3}{|c|}{ Number of samples exceeding drinking water standards } \\
\hline & & $\begin{array}{l}\text { All samples } \\
\text { (33 samples) }\end{array}$ & $\begin{array}{l}\text { Lake Champlain Basin } \\
\text { (13 samples) }\end{array}$ & $\begin{array}{c}\text { Susquehanna River Basin } \\
\text { (20 samples) }\end{array}$ \\
\hline Nitrate plus nitrite $\left(\mathrm{NO}_{2}+\mathrm{NO}_{3}\right)$, as $\mathrm{N}$ & 1,210 & 0 & 0 & 0 \\
\hline Nitrate $\left(\mathrm{NO}_{3}\right)$, as $\mathrm{N}$ & 1,210 & 0 & 0 & 0 \\
\hline Nitrite $\left(\mathrm{NO}_{2}\right)$, as $\mathrm{N}$ & ${ }^{1,2} 1$ & 0 & 0 & 0 \\
\hline
\end{tabular}

${ }^{1}$ U.S. Environmental Protection Agency (2009) maximum contaminant level.

${ }^{2}$ New York State Department of Health (2011) maximum contaminant level.

$7.0 \mu \mathrm{g} / \mathrm{L}$ in filtered water from bedrock wells), and boron (median $23 \mu \mathrm{g} / \mathrm{L}$ in filtered water from bedrock wells; median $6.6 \mu \mathrm{g} / \mathrm{L}$ in filtered water from sand and gravel wells; tables 11 and $1-5)$.

The concentrations of iron in one sample from a bedrock well (CL 149) exceeded the NYSDOH MCL and EPA SDWS of $300 \mu \mathrm{g} / \mathrm{L}$ in the filtered and unfiltered samples $(497 \mu \mathrm{g} / \mathrm{L}$ in the filtered sample; $606 \mu \mathrm{g} / \mathrm{L}$ in the unfiltered sample; tables 12 and 1-5). Samples from three bedrock wells (CL 149, CL 700, and EX1894) had concentrations of manganese that exceeded the EPA SDWS of $50 \mu \mathrm{g} / \mathrm{L}$ in unfiltered and filtered samples. However, samples from these wells did not exceed the NYSDOH MCL of $300 \mu \mathrm{g} / \mathrm{L}$. The maximum concentration of manganese was $216 \mu \mathrm{g} / \mathrm{L}$ in an unfiltered sample from bedrock well CL 700. Drinking-water standards for antimony, arsenic, barium, beryllium, cadmium, chromium, copper, lead, mercury, selenium, silver, thallium, zinc, and uranium were not exceeded (tables 12 and 1-5). Antimony, cadmium, mercury, and silver were not detected in any of the 13 Lake Champlain Basin samples collected (tables 1-1 and $1-5$ ).

In the Susquehanna River Basin, the trace elements present in the highest median concentrations in the samples were strontium (median $94 \mu \mathrm{g} / \mathrm{L}$ in sand and gravel wells, median $175 \mu \mathrm{g} / \mathrm{L}$ in bedrock wells), iron (median concentration $149 \mu \mathrm{g} / \mathrm{L}$ in unfiltered water from bedrock wells and $116 \mu \mathrm{g} / \mathrm{L}$ in filtered water from bedrock wells), barium (median $128 \mu \mathrm{g} / \mathrm{L}$ in bedrock wells, median $26.7 \mu \mathrm{g} / \mathrm{L}$ in sand and gravel wells), manganese (median concentration of $113 \mu \mathrm{g} / \mathrm{L}$ in unfiltered water from bedrock wells and $111 \mu \mathrm{g} / \mathrm{L}$ in filtered water from sand and gravel wells), and boron (median $90 \mu \mathrm{g} / \mathrm{L}$ in filtered water from bedrock wells, median $21 \mu \mathrm{g} / \mathrm{L}$ in filtered water from sand and gravel wells; tables 11 and 1-5).

The concentration of aluminum in one sample from a bedrock well (TI1031, $501 \mu \mathrm{g} / \mathrm{L}$ ) exceeded the EPA SDWS of 50 to $200 \mu \mathrm{g} / \mathrm{L}$ (tables 12 and 1-5). The concentration of arsenic in two samples - one from sand and gravel well (BM 90, 10.4 $\mu \mathrm{g} / \mathrm{L}$ ) and one from bedrock well (TI1031, $14.3 \mu \mathrm{g} / \mathrm{L}$ ) - exceeded the EPA MCL and NYSDOH MCL of $10 \mu \mathrm{g} / \mathrm{L}$. The concentration of barium in one sample from a bedrock well (BM2088, 18,300 $\mu \mathrm{g} / \mathrm{L}$ ) exceeded the NYSDOH MCL and EPA MCL of 2,000 $\mu \mathrm{g} / \mathrm{L}$. Additionally, the concentration of strontium in BM2088 was $12,900 \mu \mathrm{g} / \mathrm{L}$. The concentration of iron in three samples ( 2 bedrock wells and 1 sand and gravel) exceeded the NYSDOH MCL and EPA SDWS of $300 \mu \mathrm{g} / \mathrm{L}$ in unfiltered samples; the maximum iron concentration was $1,950 \mu \mathrm{g} / \mathrm{L}$ (TI1031). Two of the three samples also had concentrations of iron that exceeded the MCL and SDWS when filtered. The concentration of manganese in 9 of 20 samples from the Susquehanna River Basin ( 3 from sand and gravel wells, 6 from bedrock wells) exceeded the EPA SDWS of $50 \mu \mathrm{g} / \mathrm{L}$ in unfiltered samples; only 1 of the samples from those nine wells did not have an exceedance in the associated filtered sample. The concentration of manganese in four of these samples further exceeded the NYSDOH MCL of $300 \mu \mathrm{g} / \mathrm{L}$. The maximum manganese concentration was $1,170 \mu \mathrm{g} / \mathrm{L}$ (BM 90). Drinkingwater standards for antimony, beryllium, cadmium, chromium, copper, lead, mercury, selenium, silver, thallium, and zinc were not exceeded; antimony, cadmium, mercury, and silver were not detected in any of the 20 Susquehanna River Basin samples (tables 1-1 and 1-5).

\section{Pesticides}

Groundwater-quality samples were analyzed for 52 pesticides and (or) pesticide degradates. No concentrations exceeded established drinking-water standards set for pesticides and pesticide degradates. Results are reported in table 1-6.

In the Lake Champlain Basin, five pesticides and (or) pesticide degradates were detected at trace concentrations in five samples (table 1-6). Most of the pesticides detected were broadleaf herbicides or their degradates; an insecticide (disulfoton) was also detected. Three out of the 5 wells with pesticide detections are bedrock wells; 2 wells are production wells, and 3 are domestic. The most frequently detected pesticides were the degradate 2-chloro-4-isopropylamino6-amino-s-triazine (CIAT; 4 samples), the pesticide atrazine 


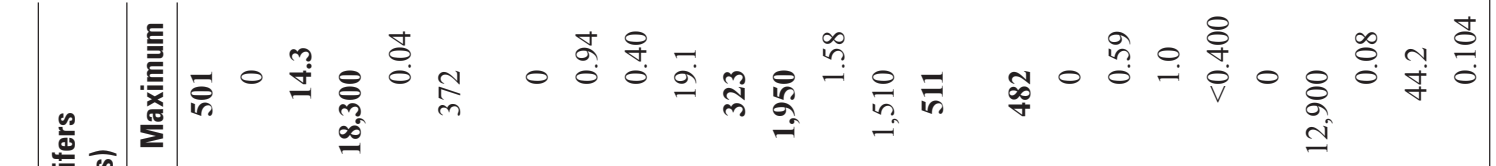

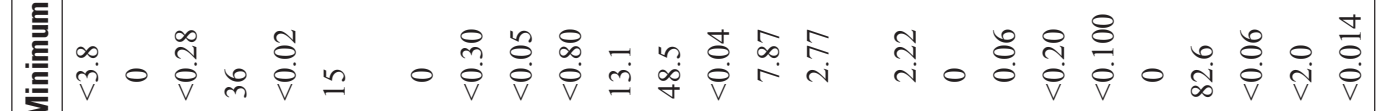

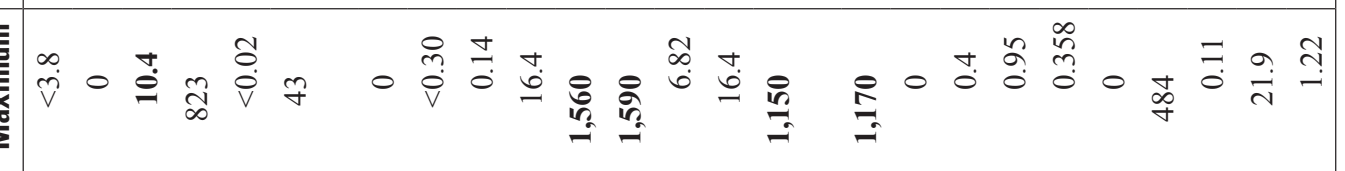

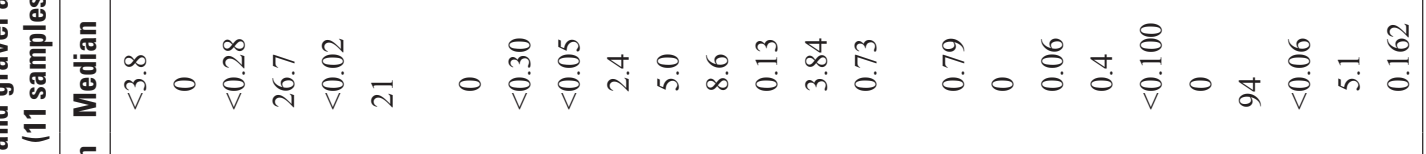

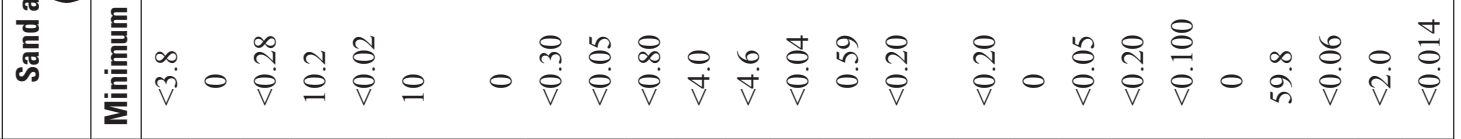

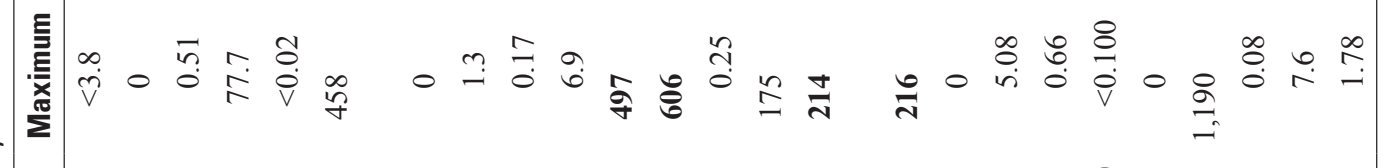

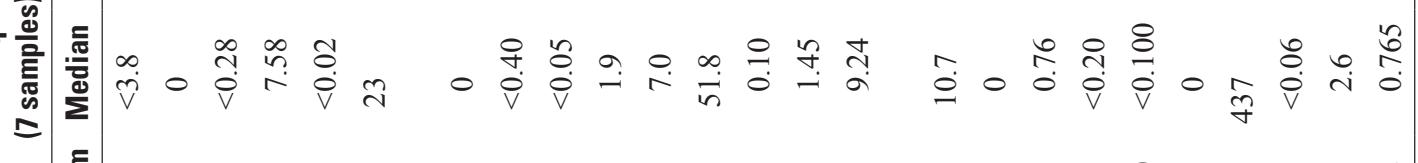
.

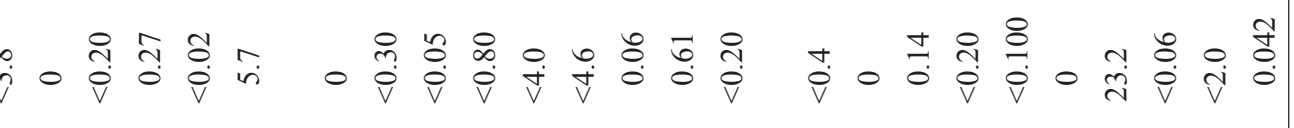

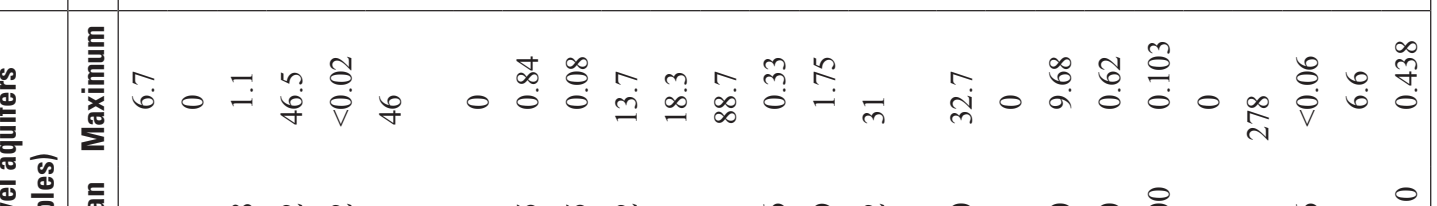

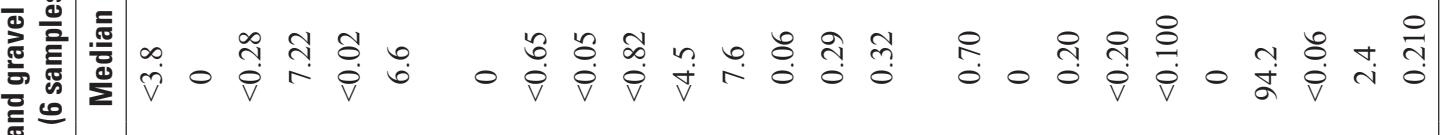

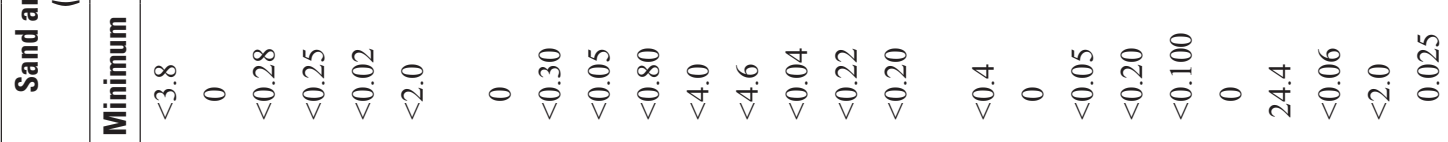

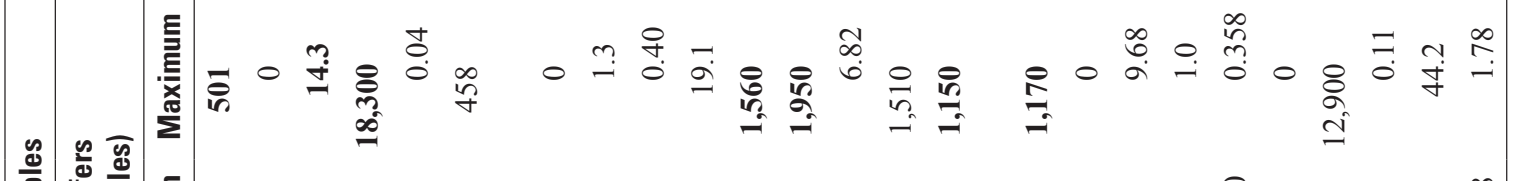

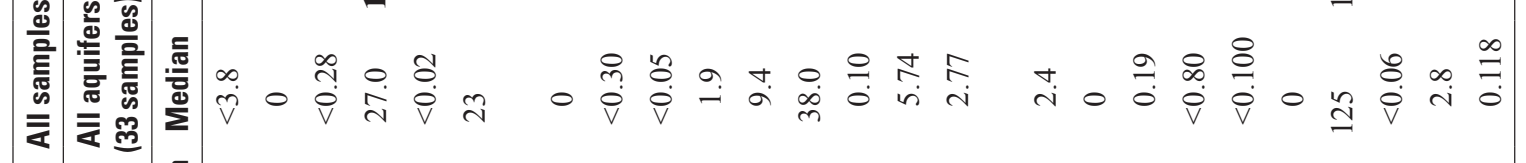

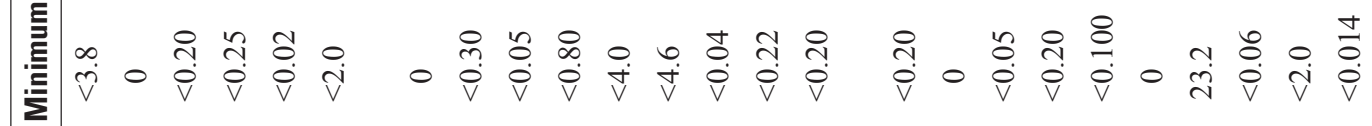

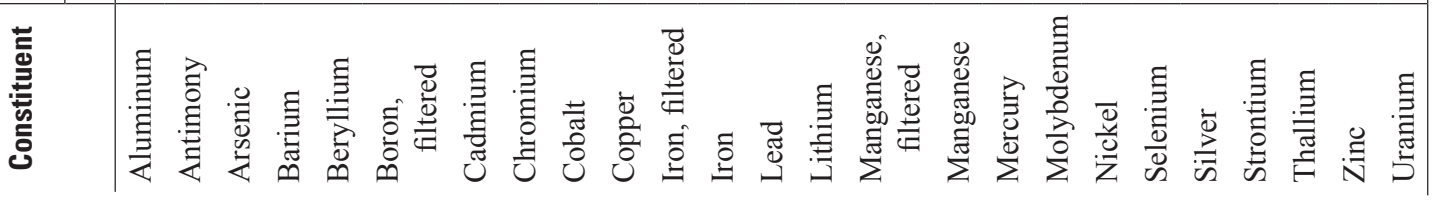


Table 12. Drinking-water standards for concentrations of trace elements and number of groundwater samples exceeding those standards collected in the Lake Champlain and Susquehanna River Basins, New York, 2014.

[All concentrations in micrograms per liter in unfiltered water]

\begin{tabular}{|c|c|c|c|c|}
\hline \multirow[b]{2}{*}{ Constituent } & \multirow[b]{2}{*}{ Drinking-water standard } & \multicolumn{3}{|c|}{ Number of samples exceeding drinking water standards } \\
\hline & & $\begin{array}{l}\text { All samples } \\
\text { (33 samples) }\end{array}$ & $\begin{array}{l}\text { Lake Champlain Basin } \\
\text { (13 samples) }\end{array}$ & $\begin{array}{c}\text { Susquehanna River Basin } \\
\text { (20 samples) }\end{array}$ \\
\hline Antimony & 2,36 & 0 & 0 & 0 \\
\hline Arsenic & 2,310 & 2 & 0 & 2 \\
\hline Cadmium & 2,35 & 0 & 0 & 0 \\
\hline Chromium & ${ }^{3,3} 100$ & 0 & 0 & 0 \\
\hline Copper & ${ }^{1} 1,000$ & 0 & 0 & 0 \\
\hline Iron, filtered & 1,3300 & 3 & 1 & 2 \\
\hline Manganese & $\begin{array}{r}3300 \\
150\end{array}$ & $\begin{array}{r}4 \\
11\end{array}$ & $\begin{array}{l}0 \\
3\end{array}$ & $\begin{array}{l}4 \\
8\end{array}$ \\
\hline Mercury & 2,32 & 0 & 0 & 0 \\
\hline Selenium & 2,350 & 0 & 0 & 0 \\
\hline Silver & 1,3100 & 0 & 0 & 0 \\
\hline Thallium & ${ }^{2,3} 2$ & 0 & 0 & 0 \\
\hline Zinc & $1,35,000$ & 0 & 0 & 0 \\
\hline Uranium & 2,330 & 0 & 0 & 0 \\
\hline
\end{tabular}

${ }^{1}$ U.S. Environmental Protection Agency (2009) secondary drinking water standard.

${ }^{2}$ U.S. Environmental Protection Agency (2009) maximum contaminant level.

${ }^{3}$ New York State Department of Health (2011) maximum contaminant level.

${ }^{4}$ U.S. Environmental Protection Agency (2009) treatment technique.

(3 samples), and the pesticide metolachlor (3 samples). The pesticide detected at the highest concentration $(0.053 \mu \mathrm{g} / \mathrm{L})$ was atrazine. More than one pesticide was detected in several samples. One sample (EX1023) had detections of four pesticides, one sample (W3220) had detections of three pesticides, and two samples (CL 700 and EX1894) had detections of two pesticides.

In the Susquehanna River Basin, atrazine, a broadleaf herbicide, and CIAT, a degradate of atrazine were detected at trace concentrations in five samples (table 1-6). Most of the wells with pesticide detections were sand and gravel production wells (four of five); the remaining well was a bedrock domestic well. CIAT was detected in all five of the samples with a pesticide detection; atrazine was detected in two of those wells with pesticide detections (C2009, TI 892). The pesticide detected at the highest concentration (estimated $0.010 \mu \mathrm{g} / \mathrm{L}$ ) was CIAT.

\section{Volatile Organic Compounds}

Groundwater-quality samples were analyzed for 34 VOCs. No concentration exceeded established drinking-water standards set for VOCs. Results are reported in table 1-7.

In the Lake Champlain Basin, VOCs were detected in samples from one sand and gravel well (EX 589) and one bedrock well (CL 149; table 1-7). The VOCs detected were the gasoline additive methyl tert-butyl ether (MTBE) and the solvent 1,1-dichloroethene. MTBE was detected in the sand and gravel production well CL $149(0.8 \mu \mathrm{g} / \mathrm{L})$, and 1,1-dichloroethene was detected in the bedrock production well EX $589(0.1 \mu \mathrm{g} / \mathrm{L})$.

In the Susquehanna River Basin, eight VOCs were detected in samples from three sand and gravel wells (BM 90, 
OG 374, and TI 921) and two bedrock wells (C1818 and TI1031; table 1-7). The VOCs detected included three trihalomethanes (THMs, which are a byproduct formed when chlorine or bromine are used as disinfectants; trichloromethane [chloroform], dibromochloromethane, and tribromomethane), four solvents (1,1,1-trichloroethane, 1,1-dichloroethane, bromodichloro-methane, and cis-1,2-dichloroethene), and one refrigerant (tetrachloromethane). The VOC detected at the highest concentration was tribromomethane $(7.0 \mu \mathrm{g} / \mathrm{L})$ in a sample from a bedrock well (TI1031). The sample from bedrock well C1818 contained detectable concentrations of five VOCs: bromodichloromethane, tribromomethane, dibromochloromethane, tribromomethane, and tetrachloromethane.

\section{Radionuclides}

Groundwater-quality samples were analyzed for radon222 activity, gross- $\alpha$ activity and gross- $\beta$ activity. Radon is currently (2016) not regulated in drinking water, however, the EPA has proposed a two-part standard for radon-222 in drinking water: (1) a 300-picocuries per liter (pCi/L) MCL for areas that do not implement an indoor-air radon-222 mitigation program and (2) an alternative MCL (AMCL) of $4,000 \mathrm{pCi} / \mathrm{L}$ for areas that do implement an indoor-air radon222 mitigation program (U.S. Environmental Protection Agency, 1999). The EPA and NYSDOH MCLs for gross- $\beta$ are both for 4 millirems per year, a dosage determination that requires knowledge of the specific radionuclide sources. The activity units (picocuries per liter) that were used to measure gross- $\beta$ radioactivity in this study are not comparable to dosage units (millirems per year) without determination of the nuclide sources; therefore, it is not possible to determine whether any of the samples exceeded the MCL for gross- $\beta$ radioactivity. Results are reported in table 1-8.

In the Lake Champlain Basin, gross- $\alpha$ activity ranged from non-detectable levels to $3.7 \mathrm{pCi} / \mathrm{L}$; the median activity was less than the detection level (tables 13 and 1-8). No samples exceeded the NYSDOH and EPA MCLs of $15 \mathrm{pCi} / \mathrm{L}$ for gross- $\alpha$ activity (tables 14 and $1-8$ ). Gross- $\beta$ activities ranged from non-detectable levels to $11.4 \mathrm{pCi} / \mathrm{L}$; the median gross- $\beta$ activity was $1.9 \mathrm{pCi} / \mathrm{L}$ for sand and gravel wells and $3.7 \mathrm{pCi} / \mathrm{L}$ for bedrock wells. Radon-222 activities in the water samples ranged from 109 to $6,300 \mathrm{pCi} / \mathrm{L}$; the median activity was $183 \mathrm{pCi} / \mathrm{L}$ for sand and gravel wells, and $480 \mathrm{pCi} / \mathrm{L}$ for bedrock wells. The highest gross- $\beta$, and radon- 222 activities were in a sample from one well, CL 848 (11.4 pCi/L; 6,300 $\mathrm{pCi} / \mathrm{L}$, respectively), that is completed in sandstone bedrock. The second highest radon-222 activity was from a well completed in crystalline bedrock (CL 700; 3,800 pCi/L). Radon222 activities in 5 of the 13 Lake Champlain Basin samples exceeded the proposed MCL of $300 \mathrm{pCi} / \mathrm{L}$; the radon-222 activity in one sample (CL 848) exceeded the proposed AMCL of $4,000 \mathrm{pCi} / \mathrm{L}$.

In the Susquehanna River Basin, gross- $\alpha$ activity ranged from non-detectable levels to $45 \mathrm{pCi} / \mathrm{L}$; the median activity was less than the detection level (tables 13 and 1-8). The gross- $\alpha$ activity of bedrock well BM2088 (45 pCi/L) exceeded the NYSDOH and EPA MCLs of $15 \mathrm{pCi} / \mathrm{L}$. Gross- $\beta$ activities ranged from non-detectable levels to $37 \mathrm{pCi} / \mathrm{L}$. Radon-222 activities in the groundwater samples ranged from 58 to 1,240 $\mathrm{pCi} / \mathrm{L}$; the medians were $670 \mathrm{pCi} / \mathrm{L}$ in sand and gravel wells, and 350 in bedrock wells. The highest radon-222 activity was in a sample from a sand and gravel well (TI 921, 1,240 pCi/L). The two highest radon-222 activities in bedrock samples were from wells completed in shale and sandstone (BM2178, 1,150 pCi/L; TI1663, 1,080 pCi/L). Radon-222 activities in 13 of the 20 Susquehanna River Basin samples exceeded the proposed MCL of $300 \mathrm{pCi} / \mathrm{L}$; no samples exceeded the proposed AMCL of 4,000 pCi/L (tables 14 and 1-8).

\section{Bacteria}

Groundwater-quality samples were analyzed for fecal indicator bacteria, including total coliform bacteria, fecal coliform bacteria, and E. coli bacteria. Heterotrophic plate count was also determined. Heterotrophic plate count is used to assess the overall bacterial load in the sample, which in conjunction with fecal indicator bacteria, allows for inferring potential sources of contamination. The NYSDOH and EPA MCLs for total coliform bacteria are exceeded when 5 percent of samples of finished water collected in 1 month test positive for total coliforms (if 40 or more samples are collected per month) or when two samples of finished water test positive for total coliforms (if fewer than 40 samples are collected per month). Results are reported in table 1-9.

In the Lake Champlain Basin, total coliform bacteria were detected in one sample from a sand and gravel well (CL 169) and two samples from bedrock wells (EX1023 and EX1894; table 1-9). Well EX1023 had a total coliform bacteria detection of 24 colony-forming units per 100 milliliters (CFU/100 mL). Fecal coliform bacteria (12 CFU/100 mL) and $E$. coli bacteria were detected in bedrock well EX1023, exceeding the EPA and NYSDOH MCLs for both fecal coliform and $E$. coli bacteria (NYSDOH and EPA MCLs are any positive result). The heterotrophic plate count ranged from $<1$ to 18 colony-forming units per milliliter $(\mathrm{CFU} / \mathrm{mL})$; no Lake Champlain Basin samples exceeded the EPA MCL of $500 \mathrm{CFU} / \mathrm{mL}$ for heterotrophic plate count.

In the Susquehanna River Basin, total coliform bacteria were detected in 1 sample from a sand and gravel well (OG 316, 13 CFU/100 mL) and 1 sample from a bedrock well (M1847, 30 CFU/100 mL; table 1-9). Fecal coliforms and $E$. coli bacteria were not detected in any samples from the Susquehanna River Basin. The heterotrophic plate count ranged from $<1$ to $421 \mathrm{CFU} / \mathrm{mL}$; no samples exceeded the EPA MCL for heterotrophic plate count. 


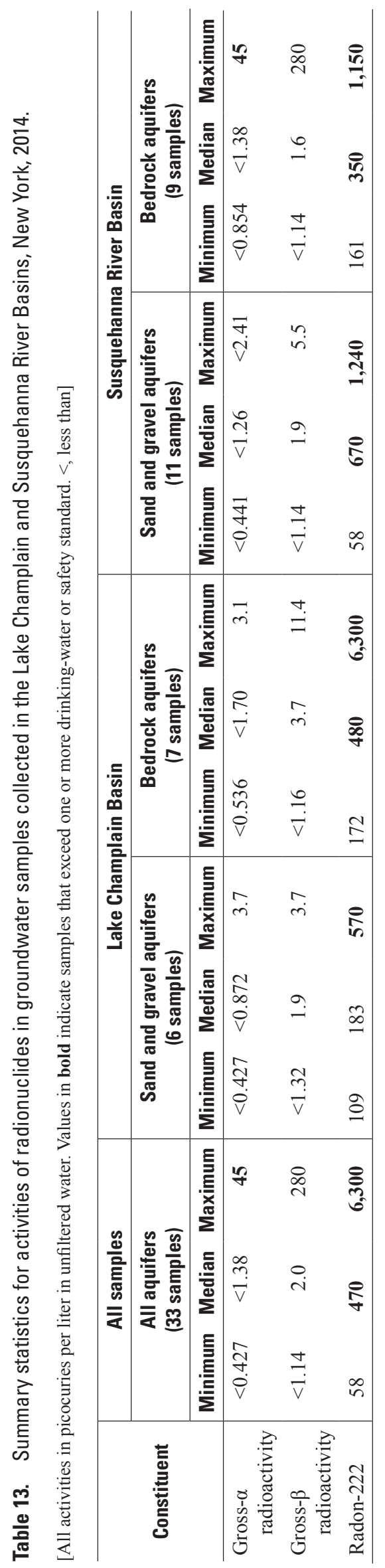


Table 14. Drinking-water standards for activities of radionuclides and number of groundwater samples exceeding those standards collected in the Lake Champlain and Susquehanna River Basins, New York, 2014.

[All activities are in unfiltered water. Activity units (in picocuries per liter $[\mathrm{pCi} / \mathrm{L}]$ ) used to measure gross- $\beta$ radioactivity in this study are not comparable to dosage units (in millirems per year [mrem/yr]). - , not applicable]

\begin{tabular}{lcccc}
\hline \multicolumn{1}{c}{ Constituent } & $\begin{array}{c}\text { Drinking-water } \\
\text { standard }\end{array}$ & $\begin{array}{c}\text { All samples } \\
\text { (33 samples) }\end{array}$ & $\begin{array}{c}\text { Lake Champlain Basin } \\
\text { (13 samples) }\end{array}$ & $\begin{array}{c}\text { Susquehanna River Basin } \\
\text { (20 samples) }\end{array}$ \\
\cline { 3 - 5 } Gross- $\alpha$ radioactivity, in $\mathrm{pCi} / \mathrm{L}$ & 1,215 & 1 & 0 & 1 \\
Gross- $\beta$ radioactivity, in $\mathrm{mrem} / \mathrm{yr}$ & 1,24 & - & - & - \\
Radon-222, in $\mathrm{pCi} / \mathrm{L}$ & 3300 & 18 & 1 & 0 \\
& 44,000 & 1 & 13 \\
\hline
\end{tabular}

${ }^{1}$ U.S. Environmental Protection Agency (2009) maximum contaminant level.

${ }^{2}$ New York State Department of Health (2011) maximum contaminant level.

${ }^{3}$ U.S. Environmental Protection Agency (2009) proposed maximum contaminant level.

${ }^{4}$ U.S. Environmental Protection Agency (2009) proposed alternative maximum contaminant level.

\section{Comparison of Results From Wells Sampled in 2004-05, 2009, and 2014}

A subset of six wells sampled in 2014 was previously sampled in 2009; of those six wells, three were also sampled in 2004-05. Of the 148 physical properties, organic compounds, and inorganic compounds analyzed for in 2014 and 2009, 140 were also analyzed for in 2004-05. Note that the NWQL annually updates the LRLs for all analytes based on method performance during the previous year of analysis. Therefore, reporting levels and the determination of whether a concentration is considered "estimated" changes annually, and concentrations of compounds could differ for this reason between 2004-05, 2009, and 2014. The rules for determining and adjusting LRLs and long-term method detection levels are outlined by the USGS Branch of Quality Systems (U.S. Geological Survey, 1999a,b). Results are reported in tables 2-1 through 2-8.

Three of the Lake Champlain Basin wells sampled in 2014 (wells EX 589, W 534, and CL 149) were sampled previously in 2009; W 534 and CL 149 were sampled in 2004-05, as well. Overall, physiochemical properties exhibited little to no change for these wells (table 2-1); however, for CL 149, color was substantially lower in 2014 (2 Pt-Co units) than in 2009 (20 Pt-Co units) and 2004-05 (15 Pt-Co units). Concentrations of nutrients, major ions, dissolved gases (2009 and 2014 only), radon-222 activities, and most trace elements exhibited little to no change (tables 2-1 to 2-4 and 2-7). The concentration of iron in the filtered sample differed substantially in the CL 149 sample (2004-05, $543 \mathrm{mg} / \mathrm{L} ; 200945.7 \mathrm{mg} / \mathrm{L}$; and 2014, $497 \mathrm{mg} / \mathrm{L}$; table 2-4). One pesticide degradate, CIAT, was detected in a sample from well W 534 in the 2009 sample $(\mathrm{E} 0.001 \mu \mathrm{g} / \mathrm{L})$ and the 2014 sample $(\mathrm{E} 0.003 \mu \mathrm{g} / \mathrm{L})$, however it was not detected in the 2004-05 sample (table 2-5). Six VOCs were detected in samples from three of the wells that were resampled. In 2009, several VOCs (all THMs) were detected in the sample from well CL 149, but were not detected in the 2004-05 or 2014 samples (table 2-6). MTBE was detected in samples from CL 149 in all three rounds of sampling; concentrations were very similar in samples across all three rounds. 1,1-dichloroethene was detected in samples from well EX 589 in 2009 and 2014; concentrations were similar across both rounds of sampling (table 2-6). Gross- $\alpha$, gross- $\beta$, and radon-222 activities exhibited little to no change for these wells (table 2-7). Total coliform bacteria and fecal coliform bacteria were not detected in the samples from wells CL 149, EX 589, and W 534 in any of the rounds of sampling. The heterotrophic plate counts in all three wells were about the same across the 2 or 3 rounds of sampling (table 2-8).

Three of the Susquehanna River Basin wells sampled in 2014 (wells BM 90, OG 316, and TI 892) were sampled previously in 2009; BM 90 was sampled in the 2004-05 round, as well. Overall, physiochemical properties exhibited little to no change for these wells (table 2-1); however, for BM 90, color was substantially lower in 2014 ( $<1$ Pt-Co units) than in 2009 (5 Pt-Co units) and 2004-05 (25 Pt-Co units). Also, dissolved oxygen from BM 90 was substantially lower in 2014 and 2009 (both $0.3 \mathrm{mg} / \mathrm{L}$ ) than in 2004-05 $(7.2 \mathrm{mg} / \mathrm{L})$. Concentrations of nutrients, dissolved gases (2009 and 2014 only), most major ions, radon-222 activities, and most trace elements showed little change for each of the three wells (BM 90, OG 316, TI 892 ; tables $2-1$ to $2-4$ and 2-7). For some compounds, however, concentrations have been increasing during each subsequent round of sampling (2004-05, 2009, and 2014) in the sand and gravel production well BM 90.

Concentrations of sodium, chloride, and dissolved solids in samples from BM 90 have increased from 2004 to 2014 to levels that each exceeded the drinking-water standards (60, 300 , and $500 \mathrm{mg} / \mathrm{L}$, respectively; table 2-2). For well BM 90, sodium concentrations increased from $53.7 \mathrm{mg} / \mathrm{L}$ in $2004-05$ 
to $70.4 \mathrm{mg} / \mathrm{L}$ in 2009 and to $103 \mathrm{mg} / \mathrm{L}$ in 2014 , chloride concentrations increased from $140 \mathrm{mg} / \mathrm{L}$ in $2004-05$ to $201 \mathrm{mg} / \mathrm{L}$ in 2009 and to $312 \mathrm{mg} / \mathrm{L}$ in 2014 , and dissolved solids concentrations increased from $546 \mathrm{mg} / \mathrm{L}$ in $2004-05$ to $736 \mathrm{mgL}$ in 2009 and to $1,080 \mathrm{mg} / \mathrm{L}$ in 2014 (table 2-2). This upward trend in concentrations is also observed for several trace elements.

The concentrations of arsenic, barium, iron (in filtered and unfiltered samples), and manganese (in filtered and unfiltered samples) have substantially increased in samples collected from 2004-05 to 2009 and to 2014. Arsenic concentrations increased to levels that exceed drinking-water standards (maximum of $10.4 \mu \mathrm{g} / \mathrm{L}$ ). Barium concentrations have increased from $508 \mu \mathrm{g} / \mathrm{L}$ (2004-05) to $823 \mu \mathrm{g} / \mathrm{L}$ (2014). Iron and manganese concentrations have exceeded drinking-water standards in filtered and unfiltered samples since 2004-05. However, concentrations of each seem to be increasing over time; for example, the concentration of iron (filtered) was $1,230 \mu \mathrm{g} / \mathrm{L}$ in $2004-05,1,400 \mu \mathrm{g} / \mathrm{L}$ in 2009 , and $1,560 \mu \mathrm{g} / \mathrm{L}$ in 2014. Similar trends have been exhibited for results in unfiltered iron samples and filtered and unfiltered manganese samples (table 2-4).

No pesticides or pesticide degradates were detected in any of the samples collected at BM 90. Samples from OG 316 and TI 892 each had detections of one pesticide and one degradate at trace levels. CIAT was detected in both the 2009 and 2014 samples from OG 316 and TI 892. Atrazine was detected in both the 2009 and 2014 samples from TI 892 but was detected only in the 2009 sample from OG 316 (table 2-5).

No VOCs were detected in any of the samples collected at TI 892. Four VOCs were detected in a 2004-05 sample from BM 90. Vinyl chloride and 1,1,1-trichloroethane were detected in the 2004-05 round of the study but not in 2009 or 2014. 1,1-dichloroethane and cis-1,2-dichloroethene were detected in samples in 2004-05, 2009, and 2014. Only one VOC, trichloromethane, was detected at OG 316 , and it was detected only in the sample collected in 2009 (table 2-6). Total coliform bacteria and fecal coliform bacteria were not detected in the samples from wells BM 90 and TI 892 in any of the rounds of sampling; however, total coliform bacteria were detected (13 CFU/100 mL) in the 2014 round of sampling at OG 316. The heterotrophic plate counts in all three wells were about the same across the 2 or 3 rounds of sampling (table 2-8).

\section{Summary}

In a study conducted by the U.S. Geological Survey (USGS), in cooperation with the New York Department of Environmental Conservation, groundwater samples were collected during June through December 2014 from 13 wells in the Lake Champlain Basin and 20 wells in the Susquehanna River Basin to characterize the overall groundwater quality in each of these basins. Sample collection and analysis followed standard USGS procedures and other documented procedures. Samples were measured for physical properties and concentrations of dissolved gases, major ions, nutrients, trace elements, pesticides, volatile organic compounds (VOCs), radionuclides, and bacteria. About 45 percent (67 of 148) of constituents analyzed for were not detected at concentrations greater than the reporting levels in any of the samples.

The depths of sand and gravel wells sampled in the Lake Champlain Basin ranged from 18 to 185 feet (ft) below land surface; the depths of bedrock wells sampled ranged from 100 to $805 \mathrm{ft}$ below land surface and are completed in clastic (sandstone), carbonate, or crystalline bedrock. Six of the 13 wells sampled are production wells, and the remaining 7 are domestic wells. The samples generally had few exceedances of State and (or) Federal drinking-water standards, although concentrations of some constituentssodium, dissolved solids, fluoride, iron, manganese, radon222, total and fecal coliform bacteria, and Escherichia coli (E. coli) bacteria - equaled or exceeded primary, secondary, or proposed drinking-water standards in 7 of the 13 wells sampled. The constituent most frequently detected in concentrations exceeding drinking-water standards was radon222 (5 of 13 samples had activities equal to or greater than the U.S. Environmental Protection Agency [EPA] proposed maximum contaminant level (MCL) of 300 picocuries per liter $[\mathrm{pCi} / \mathrm{L}])$. The highest radon-222 activities were in samples from wells completed in bedrock.

In the Lake Champlain Basin, $\mathrm{pH}$ was typically near neutral. The groundwater was typically moderately hard, and the median dissolved solids concentration was 116 milligrams per liter $(\mathrm{mg} / \mathrm{L})$ in sand and gravel wells, and $195 \mathrm{mg} / \mathrm{L}$ in bedrock wells. The ions detected in the highest median concentrations were bicarbonate, sulfate, calcium, magnesium, and sodium. The dominant nutrient was nitrate; concentrations of nitrate and nitrite did not exceed established drinking-water standards. Strontium, manganese, iron, and boron were the trace elements with the highest median concentrations. Iron concentrations exceeded drinking-water standards in samples from one well; the maximum concentration was $606 \mu \mathrm{g} / \mathrm{L}$. Manganese concentrations in three samples exceeded drinking-water standards. Five pesticides and pesticide degradates were detected in five samples; all were trace-level detections. Two samples had detections for a VOC. Radon-222 activities in 5 samples exceeded a proposed MCL; 1 sample exceeded the proposed alternative maximum contaminant level. Total coliform bacteria were detected in 3 samples, and 1 of those samples also had detections for fecal coliform bacteria and E. coli bacteria.

In the Susquehanna River Basin the depths of sand and gravel wells sampled ranged from 43.6 to $360 \mathrm{ft}$ below land surface; the depths of bedrock wells that were sampled ranged from 80 to $270 \mathrm{ft}$ below land surface. The bedrock wells are completed in clastic (shale and sandstone) or carbonate bedrock. Eleven of the 20 wells sampled are production wells, and 9 are domestic wells. The samples had several exceedances of State and (or) Federal drinking-water 
standards, and properties and concentrations of some constituents - $\mathrm{pH}$, sodium, dissolved solids, chloride, iron, manganese, arsenic, aluminum, barium, gross- $\alpha$ radioactivity, radon-222, and total coliform bacteria - equaled or exceeded primary, secondary, or proposed drinking-water standards in all of the 20 wells sampled. The constituent most frequently detected in concentrations exceeding drinking-water standards was radon-222 (14 of 20 samples had activities equal to or greater than the EPA MCL of $300 \mathrm{pCi} / \mathrm{L}$ ). The highest radon222 activities were in samples from wells completed in sand and gravel.

In the Susquehanna River Basin, sample $\mathrm{pH}$ was typically near neutral. Methane was detected in 9 of the 20 samples; the action level was exceeded in samples from one well. The groundwater tended toward moderately hard to very hard, and the median dissolved solids concentration was $278 \mathrm{mg} / \mathrm{L}$ in sand and gravel wells and $176 \mathrm{mg} / \mathrm{L}$ in bedrock wells. The ions detected in the highest median concentrations were bicarbonate, calcium, sodium, and chloride. The dominant nutrient was nitrate; concentrations of nitrate and nitrite did not exceed established drinking-water standards. Strontium, iron, barium, manganese, and boron were the trace elements with the highest median concentrations. Aluminum, arsenic, iron, and manganese concentrations exceeded drinkingwater standards in samples. One pesticide and one pesticide degradate were detected in five samples; all were trace-level detections. Eight VOCs were detected in five samples. Radon222 activities in 13 of 20 samples exceeded a proposed MCL. Total coliform bacteria were detected in two samples, and fecal coliform bacteria and $E$. coli bacteria were not detected in any samples.

\section{References Cited}

ASTM International, 2006, D5072-98(2006), Standard test method for radon in drinking water: ASTM International, accessed December 28, 2006, at http://www.astm.org/.

Busenberg, Eurybiades, Plummer, L.N., Bartholomay, R.C., and Wayland, J.E., 1998, Chlorofluorocarbons, sulfur hexafluoride, and dissolved permanent gases in ground water from selected sites in and near the Idaho National Engineering and Environmental Laboratory, Idaho, 1994-97: U.S. Geological Survey Open-File Report 98-274, 72 p. [Also available at https://pubs.er.usgs.gov/publication/ofr98274.]

Butch, G.K., Murray, P.M., Hebert, G.J., and Weigel, J.F., 2003, Water resources data, New York, water year 2002 Volume 1. Eastern New York excluding Long Island: U.S. Geological Survey Water-Data Report NY-02-1, p. 502-520. [Also available at http://pubs.usgs.gov/wdr/ wdr-ny-02-1/.]
Cadwell, D.H., 1999, Adirondack, in Surficial geologic map of New York: New York State Museum Map and Chart Series no. 40 , scale 1:250,000.

Childress, C.J.O., Foreman, W.T., Connor, B.F., and Maloney, T.J., 1999, New reporting procedures based on longterm method detection levels and some considerations for interpretations of water-quality data provided by the U.S. Geological Survey National Water Quality Laboratory: U.S. Geological Survey Open-File Report 99-193, 19 p. [Also available at https://pubs.er.usgs.gov/publication/ofr99193.]

Clesceri, L.S., Greenberg, A.E., and Eaton, A.D., eds., 1998, Standard methods for the examination of water and wastewater (20th ed.): Washington, D.C., American Public Health Association, American Water Works Association, and Water Environment Federation [variously paged].

Coates, D.R., 1966, Glaciated Appalachian plateau—Till shadows on hills: Science, v. 152, p. 1617-1619.

Connor, B.F., Rose, D.L., Noriega, M.C., Murtagh, L.K., and Abney, S.R., 1998, Methods of analysis by the U.S. Geological Survey National Water Quality Laboratory-Determination of 86 volatile organic compounds in water by gas chromatography/mass spectrometry, including detections less than reporting limits: U.S. Geological Survey OpenFile Report 97-829, 78 p., accessed February 27, 2014, at https://pubs.er.usgs.gov/publication/ofr97829.

Eckhardt, D.A.V., Reddy, J.E., and Shaw, S.B., 2009, Groundwater quality in central New York, 2007: U.S. Geological Survey Open-File Report 2009-1257, 40 p., accessed February 27, 2014, at https:/pubs.er.usgs.gov/publication/ ofr20091257.

Eckhardt, D.A.V., Reddy, J.E., and Tamulonis, K.L., 2007, Ground-water quality in the Genesee River Basin, New York, 2005-2006: U.S. Geological Survey Open-File Report 2007-1093, 26 p., accessed February 27, 2014, at https://pubs.er.usgs.gov/publication/ofr20071093.

Eckhardt, D.A.V., Reddy, J.E., and Tamulonis, K.L., 2008, Ground-water quality in western New York, 2006: U.S. Geological Survey Open-File Report 2008-1140, 36 p., accessed February 27, 2014, at https://pubs.er.usgs.gov/ publication/ofr20081140.

Eltschlager, K.K., Hawkins, J.W., Ehler, W.C., and Baldassare, Fred, 2001, Technical measures for the investigation and mitigation of fugitive methane hazards in areas of coal mining: U.S. Department of the Interior, Office of Surface Mining Reclamation and Enforcement, 124 p. [Also available at http://www.osmre.gov/resources/library/ghm/methane.pdf.]

Fisher, D.W., Isachsen, Y.W., and Rickard, L.V., 1970, Adirondack, in Geologic map of New York State: New York State Museum Map and Chart Series no. 15, scale 1:250,000. 
Fishman, M.J., ed., 1993, Methods of analysis by the U.S. Geological Survey National Water Quality LaboratoryDetermination of inorganic and organic constituents in water and fluvial sediments: U.S. Geological Survey OpenFile Report 93-125, 217 p., accessed February 27, 2014, at https://pubs.er.usgs.gov/publication/ofr93125.

Fishman, M.J., and Friedman, L.C., eds., 1989, Methods for determination of inorganic substances in water and fluvial sediments: U.S. Geological Survey Techniques of Water-Resources Investigations, book 5, chap. A1, 545 p., accessed February 27, 2014, at https://pubs.er.usgs.gov/ publication/twri05A1.

Furlong, E.T., Anderson, B.D., Werner, S.L., Soliven, P.P., Coffey, L.J., and Burkhardt, M.R., 2001, Methods of analysis by the U.S. Geological Survey National Water Quality Laboratory-Determination of pesticides in water by graphitized carbon-based solid-phase extraction and high-performance liquid chromatography/mass spectrometry: U.S. Geological Survey Water-Resources Investigations Report 01-4134, 73 p., accessed February 27, 2014, at https://pubs.er.usgs.gov/publication/wri014134.

Garbarino, J.R., and Damrau, D.L., 2001, Methods of analysis by the U.S. Geological Survey National Water Quality Laboratory-Determination of organic plus inorganic mercury in filtered and unfiltered natural water with cold vapor-atomic fluorescence spectrometry: U.S. Geological Survey Water-Resources Investigations Report 01-4132, 16 p., accessed February 27, 2014, at https://pubs.er.usgs.gov/publication/wri014132.

Garbarino, J.R., Kanagy, L.K., and Cree, M.E., 2006, Determination of elements in natural-water, biota, sediment and soil samples using collision/reaction cell inductively coupled plasma-mass spectrometry: U.S. Geological Survey Techniques and Methods, book 5, chap. B1, 88 p., accessed February 27, 2014, at http://pubs.usgs.gov/tm/2006/tm5b1/.

Garbarino, J.R., and Struzeski, T.M., 1998, Methods of analysis by the U.S. Geological Survey National Water Quality Laboratory-Determination of elements in whole-water digests using inductively coupled plasma-optical emission spectrometry and inductively coupled plasma-mass spectrometry: U.S. Geological Survey Open-File Report 98-165, 101 p., accessed February 27, 2014, at https://pubs.er.usgs.gov/publication/ofr98165.

Giese, G.L., and Hobba, W.A., 1970, Water resources of the Champlain-Upper Hudson Basins in New York State: Albany, N.Y., New York State Office of Planning Coordination, $153 \mathrm{p}$.

Hem, J.D., 1985, Study and interpretation of the chemical characteristics of natural water (3d ed.): U.S. Geological Survey Water-Supply Paper 2254, 264 p. [Also available at https://pubs.er.usgs.gov/publication/wsp2254.]
Hetcher-Aguila, K.K., 2005, Ground-water quality in the Chemung River Basin, New York, 2003: U.S. Geological Survey Open-File Report 2004-1329, 19 p., accessed February 27, 2014, at https://pubs.er.usgs.gov/publication/ ofr20041329.

Hetcher-Aguila, K.K., and Eckhardt, D.A.V., 2006, Groundwater quality in the upper Susquehanna River Basin, New York, 2004: U.S. Geological Survey Open-File Report 2006-1161, 21 p., accessed February 27, 2014, at https://pubs.er.usgs.gov/publication/ofr20061161.

Hoffman, G.L., Fishman, M.J., and Garbarino, J.R., 1996, Methods of analysis by the U.S. Geological Survey National Water Quality Laboratory-In-bottle acid digestion of whole-water samples: U.S. Geological Survey Open-File Report 96-225, 28 p., accessed February 27, 2014, at https://pubs.er.usgs.gov/publication/ofr96225.

Isachsen, Y.W., Landing, E., Lauber, J.M., Rickard, L.V., and Rogers, W.B., eds., 2000, Geology of New York-A simplified account (2d ed.): Albany, N.Y., New York State Museum/Geological Survey, 294 p.

Kenny, J.F., Barber, N.L., Hutson, S.S., Linsey, K.S., Lovelace, J.K., and Maupin, M.A., 2009, Estimated use of water in the United States in 2005: U.S. Geological Survey Circular 1344, 52 p. [Also available at https://pubs.er.usgs.gov/publication/cir1344.]

New York State Department of Health, 2011, New York State Health Department public water systems regulations: New York State Department of Health, [variously paged], accessed February 27, 2014, at https://www.health.ny.gov/ regulations/nycrr/title_10/part_5/subpart_5-1_tables.htm.

Nystrom, E.A., 2006, Ground-water quality in the Lake Champlain Basin, New York, 2004: U.S. Geological Survey Open-File Report 2006-1088, 22 p., accessed February 27, 2014, at https://pubs.er.usgs.gov/publication/ofr20061088.

Nystrom, E.A., 2007a, Ground-water quality in the Delaware River Basin, New York, 2001 and 2005-06: U.S. Geological Survey Open-File Report 2007-1098, 36 p., accessed February 27, 2014, at https://pubs.er.usgs.gov/publication/ ofr20071098.

Nystrom, E.A., 2007b, Ground-water quality in the St. Lawrence River Basin, New York, 2005-06: U.S. Geological Survey Open-File Report 2007-1066, 33 p., accessed February 27, 2014, at https://pubs.er.usgs.gov/publication/ ofr20071066.

Nystrom, E.A., 2008, Ground-water quality in the Mohawk River Basin, New York, 2006: U.S. Geological Survey Open-File Report 2008-1086, 33 p., accessed February 27, 2014, at https://pubs.er.usgs.gov/publication/ofr20081086. 
Nystrom, E.A., 2009, Groundwater quality in the Upper Hudson River Basin, New York, 2007: U.S. Geological Survey Open-File Report 2009-1240, 37 p., accessed February 27, 2014, at https://pubs.er.usgs.gov/publication/ofr20091240.

Nystrom, E.A., 2010, Groundwater quality in the Lower Hudson River Basin, New York, 2008: U.S. Geological Survey Open-File Report 2010-1197, 39 p., accessed February 27, 2014, at https://pubs.er.usgs.gov/publication/ofr20101197.

Nystrom, E.A., 2011, Groundwater quality in the Lake Champlain Basin, New York, 2009: U.S. Geological Survey Open-File Report 2011-1180, 42 p., accessed February 27, 2014, at https://pubs.er.usgs.gov/publication/ofr20111180.

Nystrom, E.A., 2012, Groundwater quality in the Delaware and St. Lawrence River Basins, New York, 2010: U.S. Geological Survey Open-File Report 2011-1320, 58 p., accessed February 27, 2014, at https://pubs.er.usgs.gov/ publication/ofr20111320.

Nystrom, E.A., and Scott, T.-M., 2013, Groundwater quality in the Mohawk River Basin, New York, 2011: U.S. Geological Survey Open-File Report 2013-1021, 43 p., accessed February 27, 2014, at https://pubs.er.usgs.gov/publication/ ofr20131021.

Patton, C.J., and Truitt, E.P., 2000, Methods of analysis by the U.S. Geological Survey National Water Quality Laboratory-Determination of ammonium plus organic nitrogen by a Kjeldahl digestion method and an automated photometric finish that includes digest cleanup by gas diffusion: U.S. Geological Survey Open-File Report 00-170, 31 p., accessed February 27, 2014, at https://pubs.er.usgs.gov/ publication/ofr20000170.

Randall, A.D., 1996, Mean annual runoff, precipitation, and evapotranspiration in the glaciated northeastern United States, 1951-80: U.S. Geological Survey Open-File Report 96-395, 2 pls., 1:250,000. [Also available at https://pubs.er.usgs.gov/publication/ofr96395.]

Randall, A.D., 2001, Hydrogeologic framework of stratifieddrift aquifers in the glaciated Northeastern United States: U.S. Geological Survey Professional Paper 1415-B, 179 p.

Reddy, J.E., 2012, Groundwater quality in the Genesee River Basin, 2010: U.S. Geological Survey Open-File Report 2012-1135, 29 p., accessed February 27, 2014, at https://pubs.er.usgs.gov/publication/ofr20121135.

Reddy, J.E., 2013, Groundwater quality in Western New York, 2011: U.S. Geological Survey Open-File Report 2013-1095, 28 p., accessed March 10, 2014, at http://pubs.usgs.gov/of/2013/1095/.
Reddy, J.E., 2014, Groundwater quality in Central New York, 2012: U.S. Geological Survey Open-File Report 2014-1226, 13 p., accessed March 9, 2015, at http://pubs.usgs.gov/of/2014/1226/.

Reddy, J.E., and Risen, A.J., 2012, Groundwater quality in the Upper Susquehanna River Basin, 2009: U.S. Geological Survey Open-File Report 2012-1045, 30 p., accessed February 27, 2014, at https://pubs.er.usgs.gov/publication/ ofr20121045.

Risen, A.J., and Reddy, J.E., 2011a, Groundwater quality in the Chemung River Basin, 2008: U.S. Geological Survey Open-File Report 2011-1112, 25 p., accessed February 27, 2014, at https://pubs.er.usgs.gov/publication/ofr20111112.

Risen, A.J., and Reddy, J.E., 2011b, Groundwater quality in the Eastern Lake Ontario Basin New York, 2008: U.S. Geological Survey Open-File Report 2011-1074, 32 p., accessed February 27, 2014, at https://pubs.er.usgs.gov/ publication/ofr20111074.

Sandstrom, M.W., Stroppel, M.E., Foreman, W.T., and Schroeder, M.P., 2001, Methods of analysis by the U.S. Geological Survey National Water Quality LaboratoryDetermination of moderate-use pesticides and selected degradates in water by $\mathrm{C}-18$ solid-phase extraction and gas chromatography/mass spectrometry: U.S. Geological Survey Water-Resources Investigations Report 01-4098, 70 p., accessed February 27, 2014, at http://nwql.usgs.gov/ Public/WRIR-01-4098.shtml.

Scott, T.-M., and Nystrom, E.A., 2014, Groundwater quality in the Upper Hudson River Basin, 2012: U.S. Geological Survey Open-File Report 2014-1084, 21 p., accessed September 8, 2014, at http://pubs.usgs.gov/of/2014/1084/.

Scott, T.-M., Nystrom, E.A., and Reddy, J.E., 2015, Groundwater quality in the Chemung River, eastern Lake Ontario, and lower Hudson River Basins, New York, 2013: U.S. Geological Survey Open-File Report 2015-1168, 41 p., accessed February 5, 2016, at http://dx.doi.org/10.3133/ ofr $20151168 /$.

Struzeski, T.M., DeGiacomo, W.J., and Zayhowski, E.J., 1996, Methods of analysis by the U.S. Geological Survey National Water Quality Laboratory-Determination of dissolved aluminum and boron in water by inductively coupled plasma-atomic emission spectrometry: U.S. Geological Survey Open-File Report 96-149, 17 p., accessed February 27, 2014, at http://pubs.usgs.gov/of/1996/0149/report.pdf.

U.S. Census Bureau, 2016, New York: U.S. Census Bureau quick facts Web page, accessed June 20, 2016, at https://www.census.gov/quickfacts/table/PST045215/36. 
U.S. Environmental Protection Agency, 1980, Prescribed procedures for measurement of radioactivity in drinking water: U.S. Environmental Protection Agency EPA 600/4-80-032, accessed February 27, 2014, at http://water.epa.gov/scitech/methods/cwa/bioindicators/ upload/2007_07_10_methods_method_900_0.pdf.

U.S. Environmental Protection Agency, 1997, Guidelines for preparation of the comprehensive state water quality assessments (305(b) reports) and electronic updates: U.S. Environmental Protection Agency EPA 841-B-97-002A and EPA 841-B-97-002B, $271 \mathrm{p}$.

U.S. Environmental Protection Agency, 1999, Proposed radon in drinking water rule: U.S. Environmental Protection Agency consumer fact sheet EPA 815-F-99006, 6 p. [Also available at https://nepis.epa.gov/Exe/ ZyPDF.cgi/910196RZ.PDF?Dockey=910196RZ.PDF.]

U.S. Environmental Protection Agency, 2009, National primary drinking water standards and national secondary drinking water standards: Washington, D.C., U.S. Environmental Protection Agency, Office of Water, EPA 816-F-09-0004, 6 p., accessed February 27, 2014, at http://www.epa.gov/safewater/consumer/pdf/mcl.pdf.

U.S. Geological Survey, 1999a, Long-term method detection levels (LT-MDL) for the U.S. Geological Survey, National Water Quality Laboratory—Definitions: U.S. Geological Survey Web page, accessed March 9, 2015, at http://bqs.usgs.gov/ltmdl/definition.shtml.

U.S. Geological Survey, 1999b, Long-term method detection levels (LT-MDL) for the U.S. Geological Survey, National Water Quality Laboratory - Calculations: U.S. Geological Survey Web page, accessed March 9, 2015, at http://bqs.usgs.gov/ltmdl/calculation.shtml.
U.S. Geological Survey, 2006, Collection of water samples (ver. 2.0): U.S. Geological Survey Techniques of WaterResources Investigations, book 9, chap. A4, accessed February 27, 2014, at http://pubs.water.usgs.gov/twri9A4/.

U.S. Geological Survey, [n.d.], National field manual for the collection of water-quality data: U.S. Geological Survey Techniques of Water-Resource Investigations, book 9, chaps. A1-A9, [variously paged]. [Also available at http://pubs.water.usgs.gov/twri9A.]

Vogelmann, J.E., Howard, S.M., Yang, Limin, Larson, C.R., Wylie, B.K., and Van Driel, Nick, 2001, Completion of the 1990s national land cover data set for the conterminous United States from Landsat thematic mapper and ancillary data sources: Photogrammetric Engineering and Remote Sensing, v. 67, p. 650-662. [Also available at http://www.mrlc.gov/downloadfile2.php?file=Vogelmann. JE_PERS.67.2001_NLCD1992.pdf.]

Wilde, F.D., Radtke, D.B., Gibs, Jacob, and Iwatsubo, R.T., eds., Processing of water samples (version 2.2, with updates through 2/2009): U.S. Geological Survey Techniques of Water-Resources Investigations, book 9, chap. A5, accessed February 27, 2014, at http://pubs.water.usgs.gov/twri9A5/.

Zaugg, S.D., Sandstrom, M.W., Smith, S.G., and Fehlberg, K.M., 1995, Methods of analysis by the U.S. Geological Survey National Water Quality Laboratory-Determination of pesticides in water by $\mathrm{C}-18$ solid-phase extraction and capillary-column gas chromatography/mass spectrometry with selected-ion monitoring: U.S. Geological Survey Open-File Report 95-181, 60 p., accessed February 27, 2014, at http://pubs.usgs.gov/of/1995/0181/report.pdf. 


\section{Appendixes}

[Available for download at http://dx.doi.org/10.3133/ofr20161153]

\section{Appendix 1. Results of Water-Sample Analyses, 2014}

Appendix 2. Results of Water-Sample Analyses, 2004-05, 2009, and 2014 

For additional information write to: Director, New York Water Science Center U.S. Geological Survey

425 Jordan Road

Troy, NY 12180-8349

Email: dc_ny@usgs.gov

Information requests:

(518) 285-5602

or visit our Web site at: http://ny.water.usgs.gov

Publishing support by:

The Pembroke Publishing Service Center 
